\title{
Cytokines in Cancer Immunotherapy
}

\author{
Thomas A. Waldmann \\ Lymphoid Malignancies Branch, Center for Cancer Research, National Cancer Institute, National Institutes \\ of Health, Clinical Center, Bethesda, Maryland 20892-1374 \\ Correspondence: tawald@helix.nih.gov
}

Cytokines that control the immune response were shown to have efficacy in preclinical murine cancer models. Interferon (IFN)- $\alpha$ is approved for treatment of hairy cell leukemia, and interleukin (IL)-2 for the treatment of advanced melanoma and metastatic renal cancer. In addition, IL-12, IL-15, IL-21, and granulocyte macrophage colony-stimulating factor (GMCSF) have been evaluated in clinical trials. However, the cytokines as monotherapy have not fulfilled their early promise because cytokines administered parenterally do not achieve sufficient concentrations in the tumor, are often associated with severe toxicities, and induce humoral or cellular checkpoints. To circumvent these impediments, cytokines are being investigated clinically in combination therapy with checkpoint inhibitors, anticancer monoclonal antibodies to increase the antibody-dependent cellular cytotoxicity (ADCC) of these antibodies, antibody cytokine fusion proteins, and anti-CD40 to facilitate tumor-specific immune responses.

\begin{abstract}
Cytokines are major regulators of the innate and adaptive immune systems that allow cells of the immune systems to communicate over short distances in paracrine and autocrine fashion. They control proliferation, differentiation, effector functions, and survival of leukocytes. In light of the ability of the immune system to recognize and destroy cancer cells, cytokines have been explored in the treatment of cancer (Goldstein and Laszlo 1988; Dranoff 2004; Lee and Margolin 2011; Nicholas and Lesinski 2011; Ardolino et al. 2015). In recent years, a number of cytokines, including interleukin (IL)-2, IL-12, IL-15, IL-21, granulocyte macrophage colony-stimulating factor (GM-CSF), and interferon (IFN)- $\alpha$ have been shown to have efficacy in preclinical murine cancer mod-
\end{abstract}

els (Fig. 1). This preclinical work has supported the evaluation of these cytokines in clinical trials. IFN- $\alpha$ was the first cytokine approved for the treatment of a human cancer (hairy cell leukemia [HCL]) in 1986. IL-2 was approved for the treatment of metastatic renal cell cancer in 1992 and advanced melanoma in 1998. Nevertheless, cytokines as monotherapy have not fulfilled the initial excitement they induced.

Soluble cytokines normally act over short distances in a paracrine or autocrine fashion (Rochman et al. 2009). Therefore, when cytokines are administered parenterally, large quantities must be administered or there is a failure to achieve effective concentrations of cytokine within the tumor. These large quantities are often associated with severe toxicities, especially

Editors: Warren J. Leonard and Robert D. Schreiber

Additional Perspectives on Cytokines available at www.cshperspectives.org

Copyright (C) 2018 Cold Spring Harbor Laboratory Press; all rights reserved; doi: 10.1101/cshperspect.a028472

Cite this article as Cold Spring Harb Perspect Biol 2018;10:a028472 
T.A. Waldmann
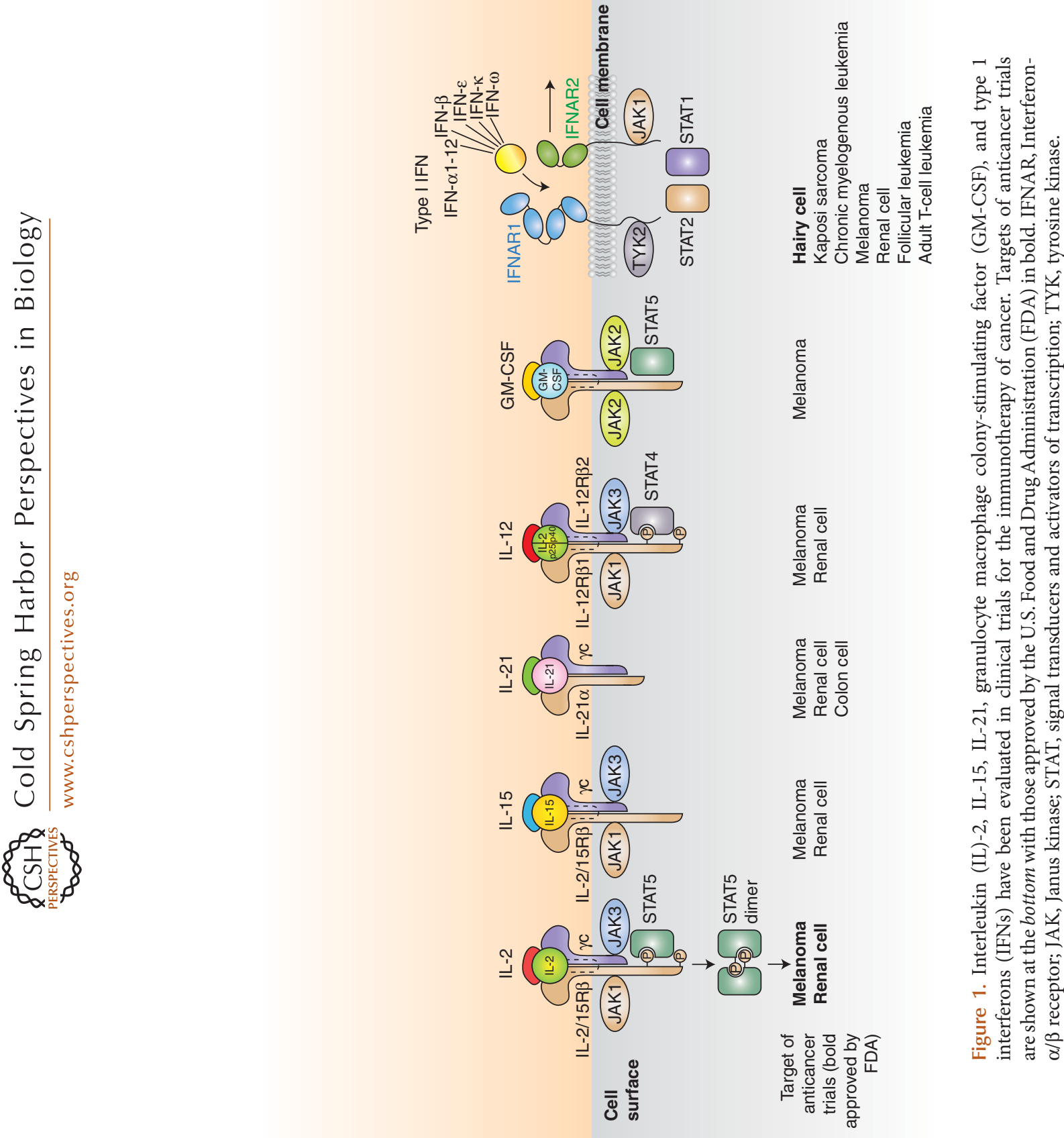

证

on

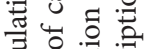

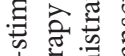

空焉

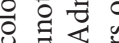

○范

品苛苞

оै ซี च

苛

눈

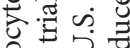

凷

때은

$\vec{i} . \Xi \vec{\nabla}$

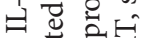

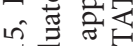

7 的

$\exists$ ¿

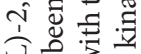

$\exists$

园害量

골

过芒

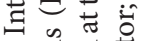

- है है

는 $\frac{\frac{1}{4}}{4}$

일

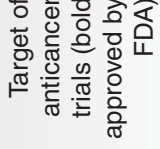


Cytokines in Cancer Immunotherapy

flu-like symptoms that include fever, malaise, hypotension, fatigue, nausea, anorexia, neutropenia, and neuropsychiatric symptoms. In the case of IL-2, a major additional impediment is the induction of the capillary leak syndrome. An additional impediment is that, for a number of cytokines, the positive actions are paralleled by the cytokine induction of immunological checkpoints that include the secretion of inhibitory factors such as IL-10 and transforming growth factor (TGF)- $\beta$, the expression of inhibitors such as triosephosphate isomerase (TIM) on the cell surface, the induction of regulatory cells, including regulatory $\mathrm{T}$ (Treg) cells, and myeloid suppressor cells, as well as one of the intracellular suppressors of cytokine signaling (SOCS) proteins that terminate signaling (Alexander et al. 2004). Furthermore, although cytokines such as IL-15 dramatically augment the number and activation of natural killer (NK) cells, such cells are inhibited by the interaction of self-class I-A,B recognition with killer-cell immunoglobulin (Ig)-like receptors (KIRs) and of major histocompatibility complex (MHC) selfclass I-E with NKG2A.

These impediments are being addressed with new strategies to augment their modest success. Because monotherapy may not be optimal, combination therapies are being evaluated with cytokines to achieve meaningful tumor responses. These approaches include cytokine engineering to augment cytokine activity, perilesional injection of cytokines, antibody-cytokine fusion proteins, infusion of cytokines along with antibodies to checkpoint proteins, the use of cytokines with anticancer vaccines, and cytokines associated with anticancer monoclonal antibodies to increase the antibody-dependent cellular cytotoxicity (ADCC) of these antibodies, thereby augmenting their efficacy (Becker et al. 1996; Carter 2001; Boyman et al. 2006; Schrama et al. 2006; Boder 2012; Levin et al. 2012; Young et al. 2014; Spangler et al. 2015). The goal of this paper is to review the cytokines involved in cancer immunotherapy and to discuss their biology and clinical application. The paper will also emphasize combinations of biological agents, novel delivery mechanisms, and directions for future investigation.

\section{INTERLEUKIN-2}

IL-2 is a $15.5-\mathrm{kDa}$ globular glycoprotein of 133 amino acids (Waldmann 1986; Taniguchi and Minami 1993; Liao et al. 2011a; Boyman and Sprent 2012). It consists of four antiparallel amphipathic $\alpha$ helixes. The three subunits of the IL2 receptor include the $\gamma$ chain $(\gamma \mathrm{c})(\mathrm{CD} 132)$ shared with IL-4, IL-7, IL-9, IL-15, and IL-21, IL-2R $\beta$ (CD122) shared with IL-15, and the (CD25) IL-2R $\alpha$ chain (Fig. 2). Three different IL-2R complexes exist and consist of combinations of the three receptor subunits (Waldmann 1991; Noguchi et al. 1993; Taniguchi and Minami 1993; Damjanovich et al. 1997; Rochman et al. 2009; Liao et al. 2011a). IL-2R $\alpha$ alone binds IL-2 with low-affinity $K_{\mathrm{d}} 10^{-8} \mathrm{M}$ and does not transduce a signal. The heterodimeric IL$2 \mathrm{R} \beta \gamma$ that binds IL-2 with intermediate affinity $K_{\mathrm{d}} 10^{9} \mathrm{M}$ can transduce an intracellular signal, and the heterotrimeric IL-2R $\alpha, \beta$, and $\gamma$ binds IL-2 with high affinity. The IL- 2 receptor signals through the Janus kinase (JAK)1, JAK3, and signal transducers and activators of transcription (STAT)5 molecules (Wang et al. 2005). IL-2 has paradoxical functions. It both acts as a $\mathrm{T}$ cell growth factor during the initiation of the immune response, and has a crucial role in terminating $\mathrm{T}$-cell responses for the maintenance of self-tolerance. IL-2 promotes the clonal expansion of antigen-activated CT8 T cells, and is a growth factor for $\mathrm{CD} 4^{+} \mathrm{T}$ cells as well as NK cells (Boyman and Sprent 2012). IL-2 facilitates the production of Ig synthesis by B cells that have been stimulated with anti-Ig M (IgM) or by CD40 ligation. As noted above, IL-2 plays a crucial role in the negative regulation of $\mathrm{T}$-cell responses. Although IL-2 signals are not essential for Treg-cell development in the thymus, they are critical for maintenance of Tregs in the periphery (Sakaguchi et al. 1995). IL-2 and all three IL- 2 receptor chains $(\alpha, \beta$, and $\gamma)$ are required for high-affinity IL-2 binding and for Foxp3 (forkhead boxp3) transcription. In addition, IL-2 plays a pivotal role in Fas-mediated activation-induced cell death (AICD) of CD4 T cells (Leonardo 1996). In the phenomenon of AICD, receptor-mediated stimulation of CD4 $\mathrm{T}$ cells by antigen at high concentrations induces 
T.A. Waldmann

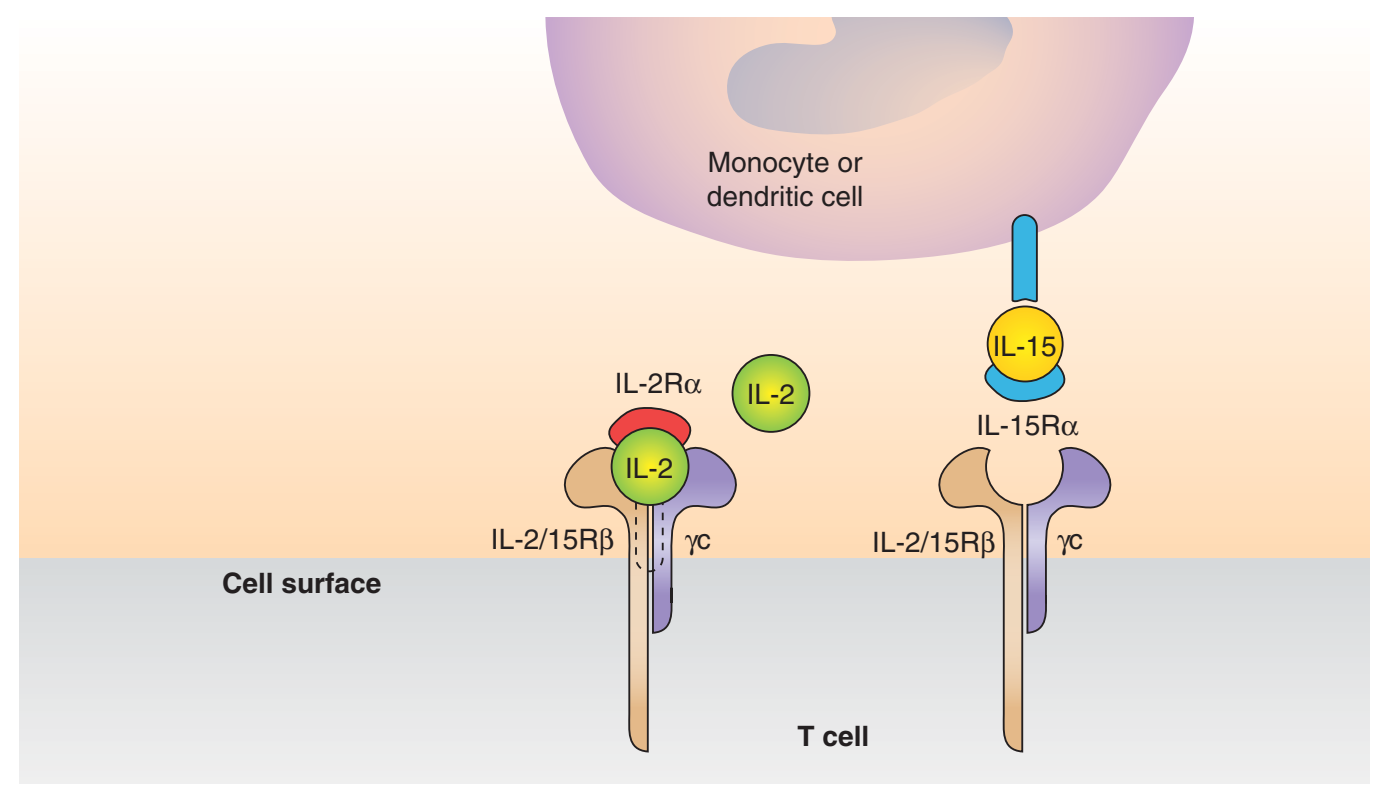

Figure 2. Model of interaction of interleukin (IL)-2 and IL-15 with their receptors. IL-2 is predominantly a secreted cytokine that binds to preformed high-affinity heterotrimeric receptors. In contrast, IL-15 is a membrane-associated molecule that signals as part of an immunological synapse between antigen-presenting cells and natural killer (NK) cells, $\gamma \Delta$, and CD8 T cells. IL-15R $\alpha$ on the surface of activated monocytes or dendritic cells (DCs) presents IL-15 in trans to cells that express IL-2/IL-15R $\beta$ and $\gamma$ chain $(\gamma \mathrm{c})$, thereby allowing signaling through these complexes. (Based on figures in Waldmann 2006.)

the expression of IL-2 and the IL-2 receptor that, in turn, interact to yield T-cell activation and cycling. Antigen stimulation of the cycling $\mathrm{T}$ cells at this stage through the T-cell antigen receptor increases the transcription and surface expression of the death effector molecule Fas ligand (FasL) and suppresses the inhibition of Fas signaling FLIP (FLICE inhibitory protein) leading to T-cell death.

The conclusions concerning the negative regulatory role of IL-2 derived from ex vivo functional studies were supported by analysis of mice with disruptive cytokine-cytokine receptor genes. IL-2 ${ }^{-/-}$and IL-2 $\mathrm{R}^{-1-}$-deficient mice develop massive enlargement of peripheral lymphoid organs associated with polyclonal $\mathrm{T}$ and B-cell expansion owing to the impairment of AICD and Tregs (Sadlack et al. 1994). IL-2R $\alpha$ deficient mice develop autoimmune diseases such as hemolytic anemia and inflammatory bowel disease.

\section{THE RESULTS OF TREATMENT OF PATIENTS WITH METASTATIC RENAL CELL CARCINOMA AND MALIGNANT MELANOMA WHO RECEIVED HIGH-DOSE RECOMBINANT IL-2 THERAPY}

Rosenberg and coworkers use high doses of IL-2 $(720,000 \mathrm{IU} / \mathrm{kg} / \mathrm{q}$ every $8 \mathrm{~h}$ for up to 14 doses over 5 days) (Rosenberg et al. 1989). Such highdose IL-2 therapy resulted in clinical responses in metastatic renal carcinoma (Rosenberg et al. 1989; Fyfe et al. 1995; Atkins et al. 1999). Based on this clinical study, the overall objective response was $14 \%$, with $5 \%$ complete responses and $9 \%$ partial responses. The responses observed were of long-term duration with complete remissions (CRs) in patients who were still in response many months after therapy.

High-dose IL-2 therapy activates not only the IL-2-specific high-affinity $\alpha, \beta$, and $\gamma$ receptors but also activates cells expressing inter- 
mediate affinity IL-2R $\beta$ and $\gamma c$ (e.g., NK cells, $\mathrm{T}$ cells, monocytes/macrophages, and $\mathrm{B}$ cells). This global activation of IL-2R $\beta$ and $\gamma c$ results in secondary proinflammatory cytokine release, and therefore is presumed responsible for the severe life-threatening side effects associated with high-dose IL-2, which include hypotension and the capillary leak syndrome (Dutcher et al. 2014). At least grade 3 toxicities in at least $20 \%$ of patients included nausea and vomiting, mental status changes, and oliguria. Given the long duration of the IL-2 therapy responses, high-dose IL-2 therapy represents a meaningful addition to the therapeutic armamentarium for patients in intensive care hospital settings.

\section{LOW-DOSE IL-2 THERAPY TARGETING THE HIGH-AFFINITY IL-2R $\alpha, \beta, \gamma$ RECEPTOR- BEARING CELLS}

Trials were designed by Soiffer et al. $(1992,1996)$ and extended by Caligiuri et al. (1993) and Fehniger and coworkers (2000) based on the known affinity of the IL-2R $\alpha, \beta, \gamma$ receptor. One basis for this IL-2 therapy was derived from studies showing that the CD56 $6^{\text {bright }} \mathrm{NK}$ cells expressed the high-affinity IL-2 receptor. Low-dose IL-2 therapy provided via continuous intravenous (i.v.) infusion over the course of 90 days was associated with a significant expansion of $\mathrm{CD} 6^{+} \mathrm{CD}^{-} \mathrm{NK}$ cells $(450 \%-900 \%$ increase) (Caligiuri et al. 1993). Although such prolonged low-dose IL-2 therapy was successful in expanding the number of NK cells, these NK cells were not activated but required higher amounts of IL2 in vivo to kill tumor cells. Therefore, low-dose IL-2 to expand NK cells has been combined with intermediate pulses of IL-2 to provide activation of the expanded NK cell pool.

A number of approaches have been used to augment the efficacy of cytokines such as IL2. Structure-based cytokine engineering has opened new opportunities for cytokines as drugs with the focus on the immunotherapeutic cytokines, IL-2, IFN, and IL-4 (Wang et al. 2005). Using in vitro evolution, the Garcia Laboratory (Levin et al. 2012) eliminated the functional requirement of IL-2 for IL-2R $\alpha$ (CD25) expression by engineering an IL-2 "superkine" with increased binding affinity for IL-2R $\beta$ (Fig. 3 ). The evolved mutations were principally in the core of the cytokine that stabilized IL-2, reducing the flexibility of a helix in the IL2R $\beta$-binding site into an optimized receptorbinding confirmation resembling that when bound to CD25. The mutations in the IL-2 superkine recapitulated the functional role of CD25 by eliciting potent phosphorylation of STAT5. When compared to IL-2, the superkine induced augmented expression of cytotoxic $\mathrm{T}$ cells, leading to improved antitumor responses in murine models with proportionately less expansion of Treg cells and reduced pulmonary edema (Levin et al. 2012; Spangler et al. 2015).

An alternative approach to augment IL-2 action was provided by Boyman et al. (2006). They induced selective stimulation of T cells with antiIL-2 immune complexes (Fig. 3). Certain monoclonal antibodies directed toward IL-2 inhibited its action. However, other antibodies coupled with IL- 2 caused massive ( $>100$-fold) expansion of CD8 cells in vivo, whereas others selectively stimulated $\mathrm{CD}^{+}{ }^{+}$Tregs. These actions were a result, in part, of increasing the survival T1/2 of IL-2. Thus, different cytokine-antibody complexes selectively boost or inhibit the immune response.

Yet another approach to augment the action and to increase the specificity of activityinvolved antibody-cytokine fusion proteins (Becker et al. 1996; Reisfeld and Gillies 1996; Lode and Reisfeld 2000; Penichet and Morrison 2001; Jin et al. 2008). Becker et al. (1996) used an antibody-IL-2 fusion protein to eradicate established tumors by augmenting activated host-immune cells, particularly $\mathrm{CD}^{+} \mathrm{T}$ cells. Young et al. (2014) also used antibodycytokine fusion proteins containing IL-2, IL12, IL-21, tumor necrosis factor (TNF)- $\alpha$, and IFN- $\alpha,-\beta$, and $-\gamma$ to guide cytokines specifically to tumor sites where they stimulated an antitumor response while avoiding the systemic toxicities of free cytokine therapy. These antitumor cytokine fusion proteins have shown antitumor activity in preclinical and earlyphase clinical studies. 
T.A. Waldmann

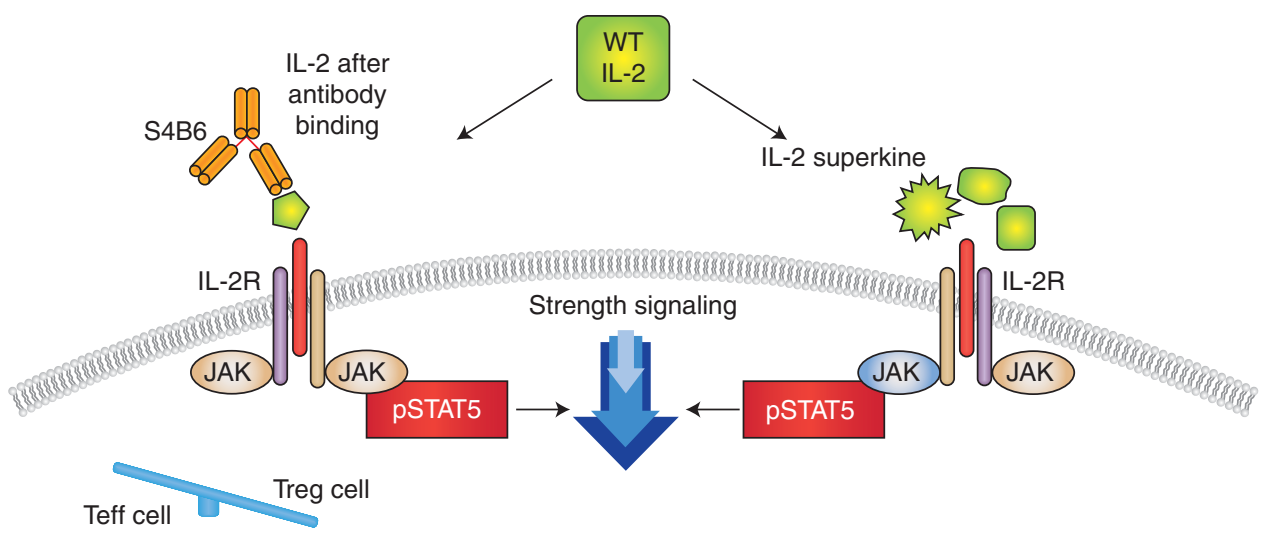

Figure 3. Different approaches to change interleukin (IL)-2 conformation to favor effector over negative regulatory function. One strategy for selectively modulating the effects of IL-2 is the development of cytokine-directed antibodies that bias activity toward specific T-cell subsets. The anti-IL-2 antibody S4B6 blocked the IL-2:IL-2R $\alpha$ interaction while also conformationally stabilizing the IL-2:IL-2R $\beta$ interaction, thus stimulating all IL-2-responsive immune cells, particularly IL-2R $\beta^{\text {hi }}$ effector cells favored over IL-2R $\alpha$ expressing regulatory T (Treg) cells. The right side shows a different mutational approach to generate a distinct IL-2R superkine variance, which uses mutations to stabilize IL-2, including a flexible helix in the IL-2R $\beta$-binding site, into an optimized receptorbinding confirmation resembling that when bound to CD25 (IL-2R $\alpha$ ) (Levin et al. 2012). The evolved mutations in super-2 recapitulated the functional role of CD25 by eliciting potential phosphorylation of signal transducers and activators of transcription 5 (STAT5) and vigorous proliferation of T cells irrespective of CD25 expression. Compared to IL-2, super-IL-2 induced superior expansion of cytotoxic T cells, leading to improved antitumor responses in vivo and eliciting proportionally less expansion of Treg cells and reduced pulmonary edema. WT, Wild type.

\section{INTERFERONS}

IFNs were first identified in 1957 by Alick Isaacs and Jean Lindenmann (Isaacs and Lindenmann 2015). The IFNs are classified by their ability to bind to specific receptors for type I (IFN- $\alpha$ and $-\beta$ ), type II (IFN- $\gamma$ ), and more recently described type III IFNs.

\section{Type I IFNs}

Type I IFNs comprise a family of cytokines that are synthesized by a variety of cells in response to viral infection, immune stimulation, and certain chemical inducers. IFN- $\alpha$ and $-\beta$ are encoded on chromosome 9 (Goldstein and Laszlo 1988). Twenty IFNs have been identified in humans. Most of the subtypes belong to the IFN- $\alpha$ group. There are two subtypes of $\beta$ (I and II) and only one type II IFN- $\gamma$. The type I IFNs signal through a common pair of receptors, IFN- $\alpha$ receptors IFNAR1 and IFNAR2 (Constantinescu et al. 1994; Muller et al. 1994a,b). The IFN re- ceptors principally signal through receptor-associated Tyk2 and JAK1 to initiate the multiple STAT1 and STAT2 phosphorylation cascades. Hundreds of genes associated with antiviral and antiproliferative functions are induced in response to different IFNs. Type I IFNs induce the expression of MHC class I molecules on tumor cells, mediate the maturation of a subset of dendritic cells (DCs), have antiangiogenic properties, activate $\mathrm{B}$ and $\mathrm{T}$ cells, increase cytotoxic cell numbers, and induce apoptosis of tumor cells.

\section{Clinical Application of IFN- $\alpha$}

IFN- $\alpha$ was approved for the treatment of some hematological malignancies, AIDS-related Kaposi sarcoma, HCL, chronic myelogenous leukemia (CML), and adjuvant therapy for patients with high-risk stage II and stage III melanoma, and has been used in the treatment of renal cell cancer (Gutterman et al. 1980; Kirkwood and Ernstoff 1984; Chronic Myeloid Leukemia 
Cytokines in Cancer Immunotherapy

Trialists' Collaborative Group 1997; Windbichler et al. 2000; Tagliaferri et al. 2005; Lange et al. 2011). However, in many cases, IFN has been replaced or relegated to therapy in second-line treatment by the development of novel reagents or combinations (Goldman et al. 2003).

IFN- $\alpha$ treatment resulted in substantial and sustained improvement in granulocyte, platelet counts, and hemoglobin levels in $77 \%$ of treated patients with HCL and at least some improvement in minor responses occurred in 90\% (Ratain et al. 1985). The percentage of patients with HCL who required blood cell or platelet transfusions decreased significantly during treatment. The median time to relapse estimated using the Kaplan-Meier method was earlier in an observation group compared to an IFN- $\alpha$ treated group. Although IFN- $\alpha$ is approved for the treatment of patients with HCL, it has been relegated to second-line treatment because nucleoside analog drugs have replaced it as primary therapy.

\section{AIDS-Related Kaposi Sarcoma}

IFN- $\alpha$ was evaluated in clinical trials in 144 patients with AIDS-related Kaposi sarcoma. A dose of 30 million units $/ \mathrm{M}^{2}$ was administered subcutaneously three times a week. $44 \%$ of asymptomatic patients responded versus $7 \%$ of symptomatic patients. The median time to response was approximately 2 mo and 1 mo, respectively, for asymptomatic and symptomatic patients. The median duration of response was approximately $3 \mathrm{mo}$ and $1 \mathrm{mo}$, respectively, for the two groups of patients.

\section{Follicular Lymphoma}

In a randomized control trial 130 patients received CHVP (cyclophosphamide, doxorubicin, teniposide, and prednisone) chemotherapy and 135 patients received CHVP therapy plus IFN$\alpha$ at 5 million units $/ \mathrm{M}^{2}$ subcutaneously three times a week for the duration of 18 months. The group receiving a combination of IFN- $\alpha$ therapy and CHVP had a significantly longer progression-free survival than the CHVP-alone group of 2.9 years versus 1.5 years $(p<001)$.

\section{Malignant Melanoma}

One hundred and forty-three patients received IFN- $\alpha$ at 30 million IU/M ${ }^{2}$ five times a week for 4 weeks, followed by 10 million IU/M ${ }^{2}$ subcutaneously three times a week for 48 weeks (Kirkwood et al. 2001). IFN- $\alpha$ therapy was begun $\leq 56$ days after surgical resection (Kirkwood et al. 1996). The remaining 137 patients were observed. IFN$\alpha$ therapy produced a significant increase in the relapse-free and overall survival. Median time to relapse for the IFN- $\alpha$-treated patients versus observation patients was 1.72 years versus 0.98 years $(p<0.01)$. In an analysis of multiple studies, there was a significant improvement in disease-free survival in 10 of 17 comparisons and overall survival in four of 14 comparisons. In a meta-analysis of seven randomized trials, IFN- $\alpha$ produced a statistically significantly better survival than those involving either hydroxyurea or busulfan. IFN- $\alpha$ produced variable results in patients with metastatic renal cell carcinoma (Amato 1999; Gollob et al. 2000; Flanigan et al. 2001). However, sunitinib produced longer progression-free survival, and response rates were higher in patients receiving sunitinib versus those receiving IFN- $\alpha$. In addition to its use in malignancy, IFN- $\alpha$ was shown to be of value in condylomata acuminata.

Bazarbachi et al. (2010) reported that azidothymidine (AZT) and IFN- $\alpha$ plus or minus arsenic therapy was associated with a response in the majority of patients with human T-cell lymphotropic virus 1 (HTLV-1)-associated adult T-cell leukemia/lymphoma (ATLL). In a metaanalysis, $100 \%$ of patients with smoldering and chronic forms of this leukemia survived 5 years, whereas $82 \%$ of patients with acute leukemia survived 5 years when treated primarily with this combination. However, for patients with lymphomatous ATLL, those who received prior intensive chemotherapy and manifested mutations of p53 or high levels of IRF4 in the malignant cells did not respond to AZT IFN- $\gamma$ therapy.

Attempts have been made to enhance IFN antiviral activity using DNA shuffling. For example, DNA sequences from all IFN- $\alpha$ subtypes were combined to generate a shuffled library that was screened for function based on antipro- 
T.A. Waldmann

liferative and antiviral activity (Stemmer 1994; Brideau-Andersen et al. 2007; Spangler et al. 2015). This screening identified two shuffled proteins, B9X25 and B9X14, with a 20- to 70fold improvement in antiviral potencies compared to IFN- $\alpha 2$. The shuffled proteins had 9to 100-fold increases in IFNAR complex affinity, respectively, compared to wild-type IFN- $\alpha 2$. Unfortunately, this and other shuffled IFNs did not advance into the clinic because of immunogenicity resulting from the numerous mutations found in the shuffled IFN products, which generated many new potential $\mathrm{T}$-cell epitopes.

\section{Toxicity}

There was considerable toxicity and morbidity associated with IFN use (Quesada et al. 1986; Zaidi and Merlino 2011). Acute symptoms with IFN administration involved flu-like constitutional symptoms, including fever, fatigue, headaches, gastrointestinal symptoms, and myalgias. IFN- $\alpha$ also produced increases in hepatic enzymes, particularly during high-dose i.v. administration. Thrombocytopenia, leukopenia, and neutropenia were common and can require a dose reduction. Quite serious were neuropsychiatric issues, including depression (45\%), confusion (10\%), and mania (less than 1\%). IFN- $\alpha$ induced depression was highly significant and in some cases suicides were reported. Diffuse electroencephalographic slowing has been shown. Thus, patients treated with high-dose IFN should be treated with antidepressants.

\section{INTERLEUKIN-12}

IL-12 is a four-bundle $\alpha$-helix heterodimeric cytokine encoded by two separate genes: $I L-12 A$ (p35) and IL-12B (p40) (Trinchieri 1995, 2003). The active heterodimer referred to as $\mathrm{p} 70$ is formed following protein synthesis. The functional high-affinity IL-12R is comprised of the units IL-12R $\beta 1$ and IL-12R $\beta 2$. IL-12 p40 binds primarily to the IL-12R $\beta 1$ subunit, whereas IL12 p35 interacts with IL-12R 32 representing the signaling transducing component. IL-12 activates both innate (NK) and adaptive cytotoxic (T-lymphocyte) immunity and inhibits angio- genesis. IL-12 is involved in the differentiation of naive T helper (Th) 0 cells into Th1 cells and stimulates the production of IFN- $\gamma$ from plasmocytoid DCs and T cells. IL- 12 augments the activity of cytotoxic $\mathrm{T}$ cells and enhances B-cell survival. IL-12 induces the production of the chemokine-inducible protein-10 (IP-10 or CXCL10), which mediates its antiangiogenesis effect (Chan et al. 1992; Lee and Margolin 2011). Because of its ability to induce innate and adaptive immune responses and its antiangiogenic activity, there has been considerable interest in evaluating IL-12 as a potential anticancer drug (Lasek et al. 2014). Limitations in its use are its induction of negative immunoregulatory IL-10 and TIM3.

IL-12 showed efficacy in a series of preclinical studies in experimental models in mice. A series of clinical trials were initiated with IL-12 (Gollob et al. 2000). In a phase I trial, the maximum tolerated dose (MTD) was $500 \mathrm{ng} / \mathrm{kg} / \mathrm{d}$. In a phase II trial, severe side effects of treatment developed in 12 of 17 enrolled patients leading to the death of two patients (Lasek et al. 2014). This resulted in the immediate halting of all trials with IL-12 by the U.S. Food and Drug Administration (FDA). An explanation for the different tolerability in phase I versus the phase II trial was a change in the dosing schedule. In the phase I trial, a single dose of IL-12 was administered before the multidose regimen. This priming dose was found to be critical for protection from the severe toxicity. After several months of suspension, clinical trials were resumed in several centers. In small nonrandomized trials, IL-12 showed modest efficacy in cutaneous T-cell lymphoma (CTCL), Hodgkin and non-Hodgkin lymphoma, and Kaposi sarcoma. More recently, alternative strategies have been attempted, including intraperitoneal administration of an IL-12 plasmid, tumor injections of an IL-12-expressing adenovirus vector, the combination of IL-12 with a vaccine containing tumor cells fused with DCs, adoptive immunotherapy with IL-12-engineered lymphoid cells, as well as IL-12 in conjunction with an anticancer monoclonal antibody to increase its ADCC (Lasek et al. 2014). In some trials, IL-12 was used with anticytotoxic T-lym- 
phocyte antigen 4 (CTLA-4) and anti-PD1 checkpoint inhibitors. The value of IL-12 in the treatment of cancer will await the results of these studies.

\section{INTERLEUKIN-21}

IL-2 1 is composed of four $\alpha$-helical bundles. IL21 is a member of the common $\gamma$ IL-2, IL-4, IL-7, IL-9, IL-15, IL-21 family of cytokines and uses the common $\gamma c$ as well as its cytokine-specific IL-21R $\alpha$ chain (Spolski and Leonard 2008). IL21 regulates both innate and adaptive immune responses. IL-21 has a major role in B-cell differentiation into plasma cells and in the development of T-follicular helper (Tfh) cells. It induces a program of $\mathrm{CD}^{+} \mathrm{T}$ cells that leads to enhanced survival, antiviral activity, and antitumor activity (Ma et al. 2003; Wang et al. 2003; Zeng et al. 2005; Cappuccio et al. 2006; Skak et al. 2008; Spolski and Leonard 2014). IL-21 has a major role in the development of Tfh cells and can promote the development of Th17 cells.

In light of its ability to enhance cytotoxic activity of $\mathrm{CD}^{+} \mathrm{T}$ cells and NK cells, IL-21 has been evaluated in the treatment of cancer (Skak et al. 2008). In studies in mice, IL-21 inhibited the growth of melanomas and fibrosarcomas (Wang et al. 2003). IL-21 has been evaluated in phase I/II clinical trials as a single agent for melanoma, renal cell cancer, and metastatic colorectal cancer (Bhatia et al. 2014). IL-21 was combined with cetuximab (Erbitux), an antibody targeting epidermal growth factor receptor (EGFR) in targeting ADCC against tumors (Steele et al. 2012). In phase I trials, the combination of IL-21 and cetuximab against stage IV colorectal cancer stable disease was achieved in $60 \%$ of patients, but the clinical trial was terminated when IL-21 was shown to have a role in chronic inflammatory bowel disease and that IL21 appears to have a major role in promoting the inflammation-induced development of colon cancer (Steele et al. 2012).

IL-21R has been shown to be expressed in diverse hematopoietic malignancies. In chronic lymphocytic leukemia (CLL), follicular lymphoma, diffuse large B-cell lymphoma (DLBCL), and mantle cell lymphoma, the apoptotic effects of IL-21 make it a candidate for use as a single agent, as well as in combination with tumorspecific antibodies. IL-21 has been used in combination with the anti-CD20 rituximab in phase I clinical trials with clinical responses seen in eight of 19 patients (Timmerman et al. 2012). In contrast, the growth-promoting effects of IL21 in multiple myeloma and Hodgkin lymphoma suggest that blocking the IL-21 signaling pathway using IL-21R-specific antibodies and an IL-21R-Fc fusion protein or via JAK inhibitors might be of therapeutic value in these hematopoietic malignancies (Spolski and Leonard 2014).

\section{GRANULOCYTE MACROPHAGE COLONY- STIMULATING FACTOR}

GM-CSF is a $23-\mathrm{kDa}$ glycoprotein that has a four- $\alpha$-helical bundle structure that binds to a heterodimeric receptor composed of subunits belonging to the type 1 cytokine receptor family. GM-CSF is the product of activated T lymphocytes, fibroblasts, endothelial cells, macrophages, and stromal cells. GM-CSF stimulates the survival of hematopoietic colony-forming cells of neutrophil, eosinophil, macrophage, megakaryocyte, and erythroid linages. GMCSF stimulates antigen presentation to the immune system. It does this by its direct effects on DCs and macrophage production, with induction of the expression of the class II MHC and Fc receptors on macrophages and DCs. GM-CSF stimulates the capacity of neutrophils, monocytes, and macrophages to mediate ADCC. GM-CSF has been evaluated in the immunotherapy of melanoma (Mach and Dranoff 2000; Li et al. 2006; Kaufman et al. 2014). In a seminal study, a panel of recombinant retroviral vectors expressing various cytokines, costimulatory molecules, or adhesion molecules was used to infect murine B16 melanoma cells. Infected cells were irradiated and injected subcutaneously into immunocompetent hosts, followed by a subsequent challenge with wild-type B16 cells (Dranoff et al. 1993; Mach and Dranoff 2000). The GM-CSF-secreting tumor vaccines conveyed $90 \%$ protection, whereas in vaccines expressing IL-2, IFN- $\gamma$ failed to mediate antitumor 
protection. Analysis of the vaccination site revealed an influx of dividing monocytes and granulocytes, as well as an increase in lymphocytes in tumor-draining lymph nodes, suggesting direct augmentation of antigen presentation and T-cell priming against the tumor. In light of the evidence of antitumor activity in preclinical models of melanoma, GM-CSF has been evaluated in completely resected stage III/IV melanoma patients; however, data from these studies have not shown consistent efficacy. GM-CSF was evaluated as intratumoral monotherapy with only modest effects-with only one partial response in two small studies but with reduced lesion size in six of seven patients and a reduction in cutaneous metastases in five of seven patients in another study. Given the evidence from preclinical studies, GM-CSF has been evaluated as an adjunct to cancer vaccines in a number of clinical studies (Dranoff 2002; Gupta and Emens 2010). In contrast to the data from murine studies, the adjuvant effect of GM-CSF in human trials was inconsistent. Two randomized perspective trials suggested that the addition of GM-CSF to melanoma vaccines did not improve cellular immune responses and indeed may have had negative effects. The inconsistent effects may be caused by contrasting effects of GMCSF, inducing DC maturation on the one hand and induction of myeloid suppressor cells on the other (Kaufman et al. 2014).

\section{INTERLEUKIN-15}

IL-15 is a 14 - to $15-\mathrm{kDa}$ member of the four- $\alpha$ helix bundle family of cytokines. IL-15 expression is controlled at the levels of transcription, translation, and intracellular trafficking. In particular, IL-15 is posttranslationally regulated by multiple controlling elements that impede translation, including 13 upstream AUGs of the $5^{\prime}$-UTR, two unusual signal peptides, and the carboxyl terminus of the mature protein (Bamford et al. 1998). The IL-15 receptor includes the $\gamma c$ subunit shared with IL-2, IL-4, IL-7, IL-15, and IL-21, and IL-2R $\beta$ shared with IL-2 as well as an IL-15-specific subunit IL$15 \mathrm{R} \alpha$. This receptor signals through the JAK1/ 3 and STAT5/STAT3 system.
IL-15 and IL-2 have several similar functions as a consequence of their sharing of receptor components IL-2/IL-15R $\beta$ and $\gamma c$ and their use of common JAK1/3 STAT3/5 signaling molecules (Fehniger and Caligiuri 2001; Waldmann et al. 2001; Fehniger et al. 2002; Waldmann 2006, 2015; Steel et al. 2012). These functions include stimulating the proliferation of activated $\mathrm{T}$ cells and their differentiation into defined effector T-cell subsets following antigen-mediated activation. Furthermore, the two cytokines facilitate the production of CTLs and Ig synthesis by B cells that have been stimulated with IgM and specific antibodies or by agonistic antiCD40. The two cytokines also stimulate the generation and proliferation of NK cells (Carson et al. 1994, 1997). In addition to these similarities, there are distinctions between the functions of IL- 2 and IL-15 in the adaptive immune response. IL-2 acts as a T-cell growth factor during initiation of a murine response but it also has a crucial role in the termination of $\mathrm{T}$-cell immune responses by AICD and by the action of Tregs (Sakaguchi et al. 1995; Leonardo 1996). In contrast with IL-2, IL-15 has no major net effect on the maintenance of the fitness of Foxp3 expressing T regs. IL-2 and IL-15 also have distinct roles in AICD. IL-2 is a critical determinant in the choice between proliferation and death (Leonardo 1996). In contrast, IL-15 is an antiapoptotic factor in several systems, in particular, in IL-15 transgenic mice, IL-2-induced AICD is inhibited (Marks-Konczalik et al. 2000). Furthermore, IL-15 promotes the maintenance of $\mathrm{CD}^{+}$ CD $44^{\text {hi }} \mathrm{T}$ cells memory phenotype cells.

These observations from ex vivo functional studies were supported by the analysis of mice with disrupted cytokine and cytokine-receptor genes. As noted above, IL-2-, IL-2R $\alpha$-, and IL-2/ IL-15R $\beta$-deficient mice developed a marked enlargement of peripheral lymphoid organs that was associated with polyclonal expansions of T- and B-cell populations (Sadlack et al. 1994). A dysregulated proliferation reflects the impairment of Treg fitness in AICD. In contrast, mice that were deficient in IL-15 or its private receptor, IL-15R $\alpha$, did not develop lymphoid enlargement, increased serum Ig concentrations, or autoimmune disease (Kennedy et al. 
2000). Instead, such mice had a marked reduction in the number of thymic and peripheral NK cells, NK T (NKT) cells, $\gamma / \delta$ T cells, and intestinal intraepithelial lymphocytes.

A most critical factor in the functional differences between IL-2 and IL-15 involves the fact that IL-2 is predominantly a secreted molecule, which in its soluble form or when linked to an extracellular matrix binds to preformed highaffinity heterotrimeric receptors at the surface of activated cells. In contrast, IL-15 is only secreted along with IL-15R $\alpha$ in small quantities and is membrane-bound (Fig. 2) (Dubois et al. 2002). IL-15 induces signaling in the context of cellcell contact at an immunological synapse. Stimulation of monocytes or DCs with IFN together with activation of $\mathrm{NF}-\kappa \mathrm{B}$ through ligation of CD40 or TLR4 induces the coordinate simultaneous expression of IL-15 and IL-15R $\alpha$. The IL15 and IL-15R $\alpha$ expressed by monocytes and DCs then become associated on the cell surface with IL-15 presented by IL-15R $\alpha$ in trans to cells that express IL-2/IL-15R $\beta$ and $\gamma c$ but not IL$15 \mathrm{R} \alpha$ (Dubois et al. 2002). Such targets of IL15/IL-15R $\alpha$ trans-presentation include NK cells and CD8 memory $\mathrm{T}$ cells. The distinctions between IL-15 and IL-2, including the fact that IL15 does not yield a net stimulation of Tregs, AICD, or extensive capillary leak syndrome, suggests that IL-15 may be superior to IL-2 in the treatment of malignancy.

\section{IL-15 AS AN IMMUNOTHERAPEUTIC AGENT: IL-15 IN PRECLINICAL IMMUNOTHERAPY MODELS}

IL-15 proved of value in the therapy of neoplasia in a number of murine models (Munger et al. 1995; Evans et al. 1997; Fehniger and Caligiuri 2001; Fehniger et al. 2002; Klebanoff et al. 2004; Roychowdhury et al. 2004; Kobayashi et al. 2005; Waldmann 2006; Dubois et al. 2008; Bessard et al. 2009; Zhang et al. 2009; Steel et al. 2012; Yu et al. 2012; Zhang et al. 2012). In particular, whereas following i.v. administration of MC38 syngeneic colon carcinoma cells wildtype mice died of pulmonary metastases within $6 \mathrm{wk}, \mathrm{IL}-15$ transgenic mice survived for more than 8 mo following infusions of the tumor cells.
Furthermore, Klebanoff and coworkers (2004) showed that IL-15 enhanced the in vivo activity of tumor-related $\mathrm{CD}^{+} \mathrm{T}$ cells in the T-cell receptor transgenic mouse (pmel-1) whose $\mathrm{CD} 8^{+}$ $\mathrm{T}$ cells recognized an epitope derived from the melanoma antigen gp100. In our studies, IL-15 was shown to prolong the survival of mice with established DC26 and MC38 colon cancers and with the TRAMP-C2 prostatic cancer (Zhang et al. 2009, 2012). On the basis of animal and laboratory trials, great interest was generated among leading immunotherapeutic experts participating in the National Cancer Institute (NCI) Immunotherapy Agent Workshop 2007 that ranked IL-15 as the most promising unavailable immunotherapeutic agent to be brought to therapeutic trials.

\section{TOXICITY, PHARMACOKINETICS, IMMUNOGENICITY, AND IMPACT ON ELEMENTS OF THE NORMAL IMMUNE SYSTEM OF RECOMBINANT IL-15 IN RHESUS MACAQUES}

The safety of IL-15 was evaluated in rhesus macaques (Mueller et al. 2005; Berger et al. 2009; Lugli et al. 2010; Waldmann et al. 2011). Human IL-15 was administered to rhesus macaques by subcutaneous (s.c.) injection for up to 14 days. Daily administration of IL-15 for 14 days caused reversible severe neutropenia, anemia, weight loss, generalized skin rash, and a massive expansion of T cells. Recombinant human (rh)IL-15 (produced in Escherichia coli) produced by the Biopharmaceutical Development Program, NCI was administered at a dosing schedule of 12 daily i.v. bolus infusions at doses of 10, 20, and $50 \mathrm{mcg} / \mathrm{kg} / \mathrm{d}$ to rhesus macaques (Lugli et al. 2010; Waldmann et al. 2011). The only biological meaningful laboratory abnormality was a grade 3/4 transient neutropenia. This neutropenia was shown to be secondary to a redistribution of neutrophils in that bone marrow examination showed increased marrow cellularity, including cells of the neutrophil series. A 12-d bolus of i.v. administration of $20 \mathrm{mcg} / \mathrm{kg} / \mathrm{d}$ of IL-15 to rhesus macaques was associated with a four- to eightfold increase in the number of circulating NK, stem, central, and 
T.A. Waldmann

effector memory CD8 T cells. Subsequently, alternative routes of administration were evaluated, including continuous i.v. (c.i.v.) infusion and s.c. administration of IL-15 (Sneller et al. 2011). The administration of IL- 15 by c.i.v. at $20 \mathrm{mcg} /$ $\mathrm{kg} / \mathrm{d}$ for 10 days led to an approximately 10 -fold increase in the number of circulating NK cells and a massive 80 - to 100 -fold increase in the number of circulating effector memory CD8 T cells. s.c. infusions at $20 \mathrm{mcg} / \mathrm{kg} / \mathrm{d}$ for 10 days led to a more modest 10-fold increase in the number of circulating effector memory CD8 $\mathrm{T}$ cells. No vascular leak syndrome, hemodynamic instability, or renal failure was observed in these studies.

\section{CLINICAL TRIALS USING IL-15 IN THE TREATMENT OF CANCER}

Five clinical trials were initiated using E. coli rhIL-15 in the treatment of cancer. The primary goal of our published trial: "A phase I study of recombinant IL-15 in adults with refractory metastatic malignant melanoma and metastatic renal cancer" was to determine the safety, adverse event profile, dose-limiting toxicity (DLT), and MTD of IL-15 administered as a daily bolus infusion for 12 days (Conlon et al. 2015). The initial patient receiving $3 \mu \mathrm{g} / \mathrm{kg} / \mathrm{d}$ developed grade 3 hypotension and another patient developed grade 3 thrombocytopenia. Therefore, the protocol was amended to add lower doses of 1.0 and $0.3 \mu \mathrm{g} / \mathrm{kg} / \mathrm{d}$. Two of the four patients given the $1.0 \mu \mathrm{g} / \mathrm{kg} / \mathrm{d}$ had persistent grade 3 alanine aminotransferase and aspartate aminotransferase elevations that were dose limiting. All nine patients with IL-15 administered at $0.3 \mu \mathrm{g} / \mathrm{kg} / \mathrm{d}$ received all 12 doses without DLT. Thus, the MTD of IL-15 was determined to be $0.3 \mu \mathrm{g} / \mathrm{kg} /$ d. Posttreatment in patients given $3 \mu \mathrm{g} / \mathrm{kg} / \mathrm{d}$ doses of IL- 15 resulted in fever and rigors beginning 2.5 to $4 \mathrm{~h}$ after the start of IL-15 infusions and blood pressure drops to a nadir of $\sim 20 \mathrm{~mm} /$ $\mathrm{Hg}$ below pretreatment levels 5 to $9 \mathrm{~h}$ after the infusion. These changes were concurrent with a maximum of 50-fold elevations of circulating IL- 6 and IFN- $\gamma$ concentrations. Flow cytometry of peripheral blood lymphocytes revealed a dramatic efflux of NK and effector memory $\mathrm{T}$ cells from the circulating blood within minutes of IL15 administration followed by influx and hyperproliferation, leading to a 10 -fold expansion of NK and $\gamma / \delta$ T cells that ultimately return to baseline. Furthermore, there were significant increases in the number of CD8 memory phenotype $\mathrm{T}$ cells. In this first-in-human phase I trial there were no responses, with stable disease as the best response. However, five patients manifested a decrease between $10 \%$ and $30 \%$ of their marker lesions and two patients had clearing of lung lesions. Subsequently, alternative dosing strategies were used, including c.i.v. and s.c. infusions, so that a lower $\mathrm{C}_{\max }$ would be achieved in trials that have been completed (Waldmann 2015).

When rhIL-15 was administered subcutaneously Monday-Friday for 2 weeks for a given dose, the $\mathrm{C}_{\max }$ was approximately 10 -fold less than that observed with bolus infusion. In general, the administration was well tolerated with the MTD of $3.0 \mathrm{mcg} / \mathrm{kg} / \mathrm{d}$, which was 10 -fold greater than that observed with bolus infusions (unpubl.). Among 22 patients, there was one serious adverse event at $2.0 \mathrm{mcg} / \mathrm{kg} / \mathrm{d}$ : grade 2 pancreatitis in a patient with metastatic melanoma 3 days after completing cycle one. The mean fold increase in the circulating NK cells was 11.8 -fold in the cohort receiving a $3.0 \mathrm{mcg} / \mathrm{kg}$ dose. In contrast, the mean fold increase in the circulating CD8 $\mathrm{T}$ cells was relatively modest with 3.2 -fold for the $3.0 \mathrm{mcg} / \mathrm{kg}$ dose cohort.

In patients receiving rhIL- 15 by continuous i.v. infusion for 10 days, the MTD was $2.0 \mathrm{mcg} /$ $\mathrm{kg}$ (K Conlon and TA Waldmann, unpubl.). The patients manifested a marked reduction in numbers of circulating NK cell numbers early during the infusion followed by a return to normal and 5- to 10-fold increased levels. Interestingly, in addition, they showed a phenomenon characterized by a major burst in the number of NK cells that occurred 1 to 2 days following cessation of the 10-day i.v. infusion with a 30 -fold increase in the circulating total NK numbers and more than a 350 -fold increase in the number of CD56 $6^{\text {bright }}$ NK cells. In a correlative study, the latter cells were shown to be effective as cytotoxic agents in diverse assays, including ADCC (S Dubois and TA Waldmann, unpubl.). These latter results 
support the use of continuous i.v. infusion of IL-15 with anticancer monoclonal antibodies to augment their ADCC and efficacy as anticancer agents (see below).

IL-15 has been engineered to exert both increased agonistic and inhibitory effects. Mortier and colleagues (2006) designed a truncated version of IL-15R $\alpha$ extracellular domain fused to IL-15 that activated IL-15R $\alpha$-deficient cells by stabilizing the signaling-complex formation analogous to the effects of IL-2 superkine on cells that lack IL-2R $\alpha$. The IL-15 fusion generated by Mortier and colleagues enhanced the proliferative and antiapoptotic effects of IL-15. Zhu et al. (2009) generated IL-15 agonists by increasing the affinity of the cytokine for IL$2 \mathrm{R} \beta$, thereby impacting interface stability. Another focus of IL-15 engineering has been to produce antagonists to counteract its immunostimulatory activity. Pettit and colleagues (1997) identified the Q108 residue of IL-15 critical for $\gamma c$ interaction, so that when this residue is deleted, one thereby abrogates cytokine-mediated proliferation. Thus, engineered examples of IL2 and IL-15 could have therapeutic utility in many aspects of immune regulation.

\section{IL-15/IL-15R $\alpha$}

Although IL-15 may show efficacy in the treatment of patients with metastatic malignancy, it is not optimal when used in monotherapy for cancer. A particular challenge is that there is only low-level expression of IL-15R $\alpha$ on resting DCs (Chen et al. 2012a). Physiologically, IL-15 is produced as a heterodimer in association with IL-15R $\alpha$ following stimulation of antigen-presenting cells with IFN, agonistic anti-CD40, or Toll-like receptor signaling (Schluns et al. 2004; Mortier et al. 2008). In mice, it is only the heterodimer that is stably produced and transported to the surface of the cell. On cleavage from the cell surface, minor quantities of IL$15 \mathrm{R} \alpha / \mathrm{IL}-15$ were associated in the serum as the sole form of circulating IL-15. To address the issue of deficient IL-15R $\alpha$, both IL-15/IL$15 \mathrm{R} \alpha$ and IL-5R $\alpha$ IgFc had been produced and entered into clinical trials that evaluated patients with metastatic malignancy (Tinhofer et al.
2000; Chertova et al. 2013; Pharmaceutical Business Review 2013).

It is clear from the results of clinical trials with IL-15 or IL-15/IL-15R $\alpha$ that to make a major impact for cancer therapy, IL-15 must be administered in combination therapy where it optimizes the action of agents that already have an action, albeit inadequate, in the treatment of cancer.

\section{AGENTS TO RELIEVE CHECKPOINTS ON THE IMMUNE SYSTEM TO OPTIMIZE IL-15}

IL-15 is associated with the expression of immunological checkpoints, including IL-10, TIGIT, and the expression of PD1 on CD8 $\mathrm{T}$ cells (Yu et al. 2010). In addition, IL-15 was shown to be critical in the maintenance of $\mathrm{CD} 122^{+}$ $\mathrm{CD}^{+}$Tregs. To address the issue of induced checkpoints, IL-15 was administered with agents to remove such checkpoints with antibodies directed toward CTLA-4 and programmed death ligand-1 (PD-L1) (Yu et al. 2010, 2012). In the CT26, MC38 colon carcino$\mathrm{ma}$, and TRAMP-C2 prostatic cancer syngeneic tumor models, IL-15 alone provided only modest antitumor activity. The addition of either anti-CTLA-4 or anti-PD-L1 alone in association with IL-15 did not augment the action of IL-15. However, tumor-bearing mice receiving IL-15 in combination with both anticheckpoint antibodies together manifested a marked prolongation of survival.

\section{COMBINATION THERAPY USING IL-15 WITH ANTICANCER MONOCLONAL ANTIBODIES TO AUGMENT THEIR ANTIBODY-DEPENDENT CELLULAR CYTOTOXICITY}

The predominant approaches involving cytokines when used alone are based on the hypothesis that the host is making an immune response albeit inadequate to their tumor, and this action can be augmented by the administration of the cytokine. However, these cytokines could also be used in drug combinations where an additional coadministered drug provides specificity directed toward the tumor. In particular, IL-15 
T.A. Waldmann

could be used with anticancer vaccines, cellular therapy, or with tumor-directed monoclonal antibodies (Sondel and Hank 1997; Moga et al. 2008; Roberti et al. 2011). Given the capacity of IL-15 to dramatically increase the number and activation state of NK cells and monocytes, a very attractive antitumor combination strategy would be to use the optimal IL-15 agent in conjunction with an antitumor monoclonal antibody to augment its ADCC. Vincent and colleagues (2014) reported highly potent antiCD20-RIL-I immunocytokine targeting of established human B-cell lymphomas in severe combined immune deficiency (SCID) mice. Clinical trials have been initiated to evaluate this strategy. Rituximab in association with IL15 is being used in the treatment of relapsed and refractory follicular lymphoma. Furthermore, we have initiated a clinical trial using alemtuzumab (CAMPATH-1/anti-CD52) along with rhIL-15 in the treatment of patients with HTLV-1-associated adult T-cell leukemia (ATL), a disorder in which alemtuzumab alone has provided responses.

\section{IL-15 PLUS AGONISTIC ANTI-CD40 ANTIBODY}

It has been shown that the administration of $\gamma$ cytokines leads to the induction of intracellular checkpoints, including cytokine-inducible $\mathrm{SH} 2$ containing protein (CIS) and SOCS-3 (Sckisel et al. 2015). This expression of SOCS3 in turn leads to inadequate CD4 help and the induction of "helpless" CD8 T cells. In a series of studies, it was shown that an agonistic anti-CD40 or CD40 ligand can substitute for inadequate CD4 cells, thereby leading to the generation of antigenspecific CD8 cytotoxic T cells (Bennett et al. 1998; Ridge et al. 1998; Schoenberger et al. 1998; Sckisel et al. 2015). In the murine syngeneic TRAMP-C2 tumor model, we showed that either IL-15 alone or with an agonistic antiCD40 antibody (FGK 4.5) prolonged the survival of the TRAMP-C2 tumor-bearing mice (Zhang et al. 2009, 2012). Moreover, we showed that the combination of IL-15 with anti-CD40 produced markedly additive effects that were curative in the majority of mice when compared to either agent alone. This combination appeared to circumvent the problem of "helpless" CD8 T cells, whereas administration of IL-15 or anti-CD40 alone did not augment the number of tumor-specific tetramer-positive CD8 T cells in the TRAMP-C2 model system; administration of the combination of IL-15 plus the agonistic anti-CD40 antibody was associated with a meaningful increase in the number of TRAMPC2 tumor-specific SPAS-1/SNC9-H8 tetramerpositive CD8 $\mathrm{T}$ cells. It is hoped that with the diverse approaches discussed IL-15 will take a place in the combination treatment of cancer (Zhang et al. 2009, 2012).

\section{CYTOKINE DISORDERS ASSOCIATED WITH MALIGNANCY}

The studies that have just been discussed focus on the use of cytokines to increase patient immune responses to their tumor. Other efforts have the opposite goal of diminishing cytokine action in situations in which disorders of their expression play a pathogenic role in the malignancy. The $\gamma$ cytokines and their signaling pathway appear frequently disordered in lymphoid malignancy. In the case of T-cell malignancy, abnormal activation of the $\gamma$-cytokine receptor JAK/STAT system in the presence and absence of mutations of these proteins was shown to be pervasive in a proportion of patients with diverse T-cell malignancies as assessed by pSTAT3 and pSTAT5 phosphorylation and nuclear translocation (Chen et al. 2012b; Kucuk et al. 2015; TA Waldmann, unpubl). Activating mutations predominantly of the SH2 domains of STAT3 and STAT5 and the pseudokinase domains of JAK1 and JAK3 were described in some but not all cases with activation of the signaling pathway. However, activating JAK and STAT mutations were not sufficient to initiate leukemic cell proliferation but rather only augmented signals from upstream in a cytokine-cytokine receptor pathway. Even with mutations of JAK and STAT, activation required the full pathway, including the cytokine and cytokine receptor acting as a scaffold and docking site for the required downstream JAK/STAT elements. 
The fundamental insight that disorders of the $\gamma \mathrm{c} / \mathrm{JAK} / \mathrm{STAT}$ system are pervasive in T-cell malignancy suggests novel therapeutic approaches discussed below. In addition to activating mutations of the receptor and JAK/ STAT system, certain T-cell malignancies were shown to have an increased expression of select $\gamma c$ cytokines that led to augmented STAT/JAK signaling. Such increases in $\gamma$ cytokine production were observed in HTLV-1-associated ATL (Tendler et al. 1990; Migone et al. 1995; Chen et al. 2008; Ju et al. 2011). ATL is an aggressive T-cell lymphoproliferative disorder characterized by the presence of malignant CD4, CD25expressing cells in the peripheral blood and in lymphoid and other tissues. Epidemiological studies showed clear association of disease with the presence of the retrovirus HTLV-1. The retrovirus HTLV-1 encodes a $40-\mathrm{kDa}$ protein Tax that transactivates two autocrine (IL-2/ IL-2R $\alpha$, IL-15/IL-15R $\alpha$ ) and one paracrine (IL-9) $\gamma$ cytokine. Associated with these two autocrine and paracrine pathways, the ex vivo leukemic cells proliferate spontaneously. These cytokine-cytokine receptor loops lead to activation of the JAK1, JAK3, and STAT5 signaling pathway, and the associated ex vivo spontaneous proliferation that was inhibited by tofacitinib.

IL-15 has been reported to play a role in CTCL (Dobbeling et al. 1998; Leroy et al. 2001). IL-15 expression was shown in CTCL tumor tissues, and IL-15 was stimulatory for CTCL cells in vitro. Analysis ex vivo of Sézary cells and CTCL cell lines by reverse transcription polymerase chain reaction (RT-PCR) indicated that these cells expressed IL-15 in messenger RNA (mRNA). In CTCL cells, there was down-regulation of ZEB1, a candidate tumor suppressor that normally inhibits IL-2 and IL-15 expression (Nakahata et al. 2010). Furthermore, there was a report of hypermethylation of the ZEB1-binding site in the promoter of IL-15 (Mishra et al. 2015). Thus, IL-15 appears to be a growth and viability factor for CTCL cell lines, and may play an important role in CTCL biology.

Gene-expression analysis of human angioimmunoblastic T-cell lymphoma (AITL), a malignancy of Tfh cells, showed that essentially all cases expressed elevated levels of transcripts for IL-21, IL-21R, and a series of genes associated with Tfh cell development and function (Jain et al. 2015).

\section{THE CYTOKINE-CYTOKINE RECEPTOR AND JAK/STAT SYSTEM AS TARGETS FOR TREATMENT OF MALIGNANCY}

As just noted, disorders of the $\gamma$ cytokine, JAK/ STAT signaling pathway are pervasive in T-cell malignancy, suggesting new molecular targets and novel therapeutic opportunities that may revolutionize the treatment of these tumors, which are usually associated with a very poor prognosis. Such therapeutic approaches include targeting the $\gamma c$ cytokines directly, agents that block cytokine receptor interactions, and JAK kinase inhibitors (Fig. 4). Such diverse approaches include the use of neutralizing antibodies to $\gamma$ c-receptor-dependent cytokines (IL-2, IL-15, and IL-21 antibodies), blocking antibodies to their receptors, small molecule inhibitors interdicting cytokine-cytokine receptor interaction, and JAK kinase inhibitors (FerrariLacraz et al. 2001, 2004). Antibodies directed to IL-15 have been evaluated in rheumatoid arthritis and may be of value in the treatment of CTCL in which disorders of IL-15 have been identified. The specific $\alpha$ chains of the $\gamma c$ cytokines and IL$2 / \mathrm{IL}-15 \mathrm{R} \beta$ shared by IL- 2 and IL- 15 have been shown to be valuable targets in the treatment of select T-cell malignancies (Vincenti et al. 1998; Waldmann et al. 2001, 2007; Berkowitz et al. 2014). Monoclonal antibodies directed toward the specific IL-2 receptor subunit IL-2R $\alpha$ have been approved by the U.S. FDA for use in the prevention of organ transplant rejection and in the treatment of autoimmunity. Furthermore, anti-IL-2R $\alpha$ (daclizumab) anti-Tac (Zenapax/ Zinbryta) has been shown to be of value in the treatment of patients with smoldering and chronic ATL (Berkowitz et al. 2014). The rationale for this target was that IL-2R $\alpha$ was not expressed by most normal resting cells with the exception of Tregs but was expressed by various T-cell leukemias, including ATL. An antibody to IL-2/IL$15 \mathrm{R} \beta$, Hu-Mik $\beta 1$ has been used to inhibit IL-15 action in patients with large granular lymphocytic leukemia (LGL) (Waldmann et al. 2013). 
T.A. Waldmann

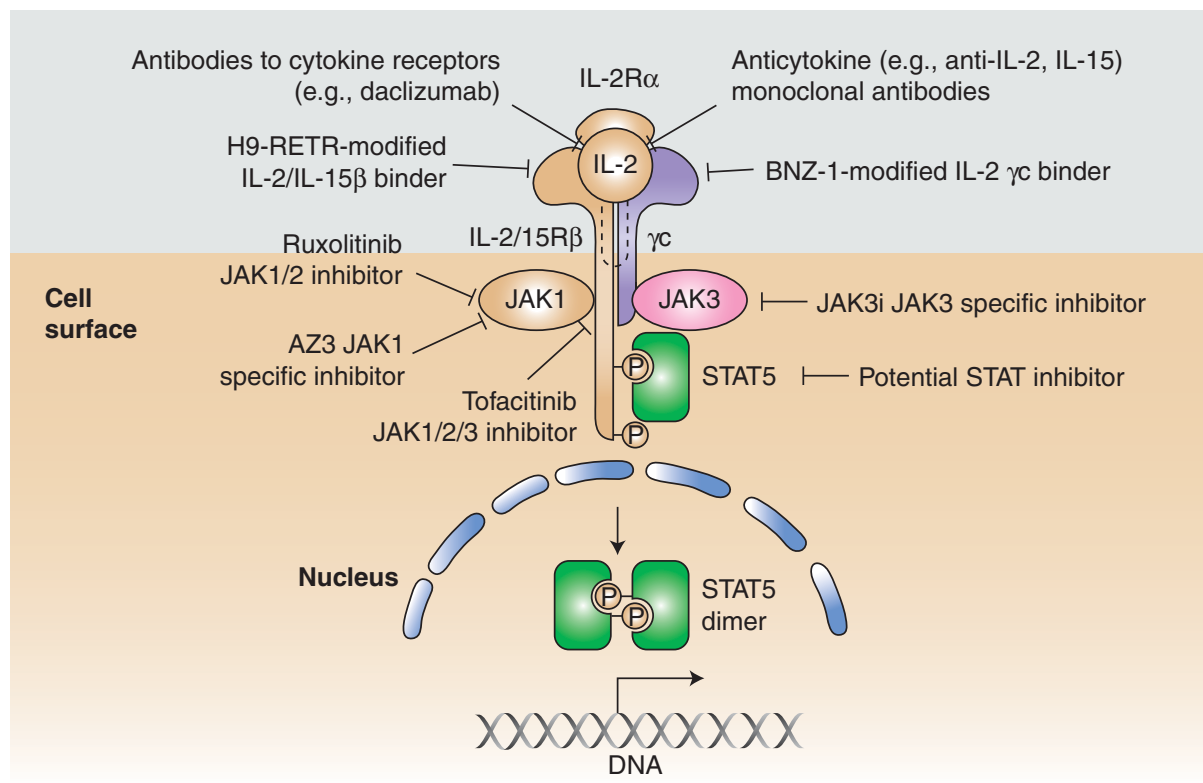

Figure 4. A series of approaches has been developed to block $\gamma$ chain $(\gamma c)$ cytokine, Janus kinase/signal transducers and activators of transcription (JAK/STAT) signaling in T-cell malignancies and autoimmune disorders. Such therapeutic approaches include targeting the $\gamma c$ cytokines directly, agents that block cytokine receptor interactions, and JAK kinase inhibitors. H9-RETR, the RETR mutant of H9 super-IL-2. (This figure was previously published as Figure 4 in Waldmann et al. 2017. It is now reproduced with permission.)

Recently, two modifications of IL-2 have been generated that block binding of normal IL-2 and IL-15 to IL-2/IL-15R $\beta$ and $\gamma$ c, thereby simultaneously inhibiting the actions of both IL2 and IL-15 (Fig. 5). BNZ-1 binds only to the $\gamma c$ but not IL-2/IL-15R $\beta$ (Nata et al. 2015). In parallel, the RETR mutant of H9 super-IL-2 (denoted H9-RETR) binds tightly to IL-2/IL-15R $\beta$ but not $\gamma \mathrm{c}$ (Mitra et al. 2015). Both agents prevent the heterodimerization of IL- $2 \mathrm{R} \beta$ with $\gamma c$ that is required for signaling. These agents are being evaluated in murine xenograft models of ATL.

As noted above, a subset of patients with virtually all forms of $\mathrm{T}$-cell malignancies require the activation of JAKs for malignant T-cell proliferation, thus providing the scientific basis for the use of JAK inhibitors in the treatment of patients with T-cell malignancy (Koskela et al. 2012; Crescenzo et al. 2015). The JAK1/2 inhibitor ruxolitinib and the JAK1/2/3 inhibitor tofacitinib diminished the proliferation of malignant T-cell lines and of ex vivo malignant leukemic cells supporting the use of such inhib- itors (Leonard and O'Shea 1998; Ju et al. 2011; O'Shea et al. 2013). A clinical trial using the JAK1/2 inhibitor ruxolitinib is underway in patients with smoldering and chronic ATL wherein HTLV-1 Tax transactivates IL-2, IL-15, and IL-9 systems (Chen et al. 2008; K Conlon and TA Waldmann, unpubl.). With rare exceptions, T-cell malignancies are associated with activation of $\gamma c$ cytokine, JAK1/3, STAT3/5 signaling but not activation of JAK2. However, both tofacitinib and ruxolitinib inhibit JAK2 in addition to the desired JAK1 and JAK3. This off-target JAK2 inhibition interferes with the signaling mediated by thrombopoietin, erythropoietin IL-3, IL-5, and GM-CSF, leading to thrombocytopenia, anemia, and neutropenia, which in turn are associated with an increased incidence of infections, including herpes zoster and tuberculosis. In light of the toxicities caused by JAK2 inhibition, agents with greater JAK specificity are being developed. Filgotinib, which preferentially inhibits JAK1 is in the clinic. However, JAK1 activates and inhibits cytokines, including 


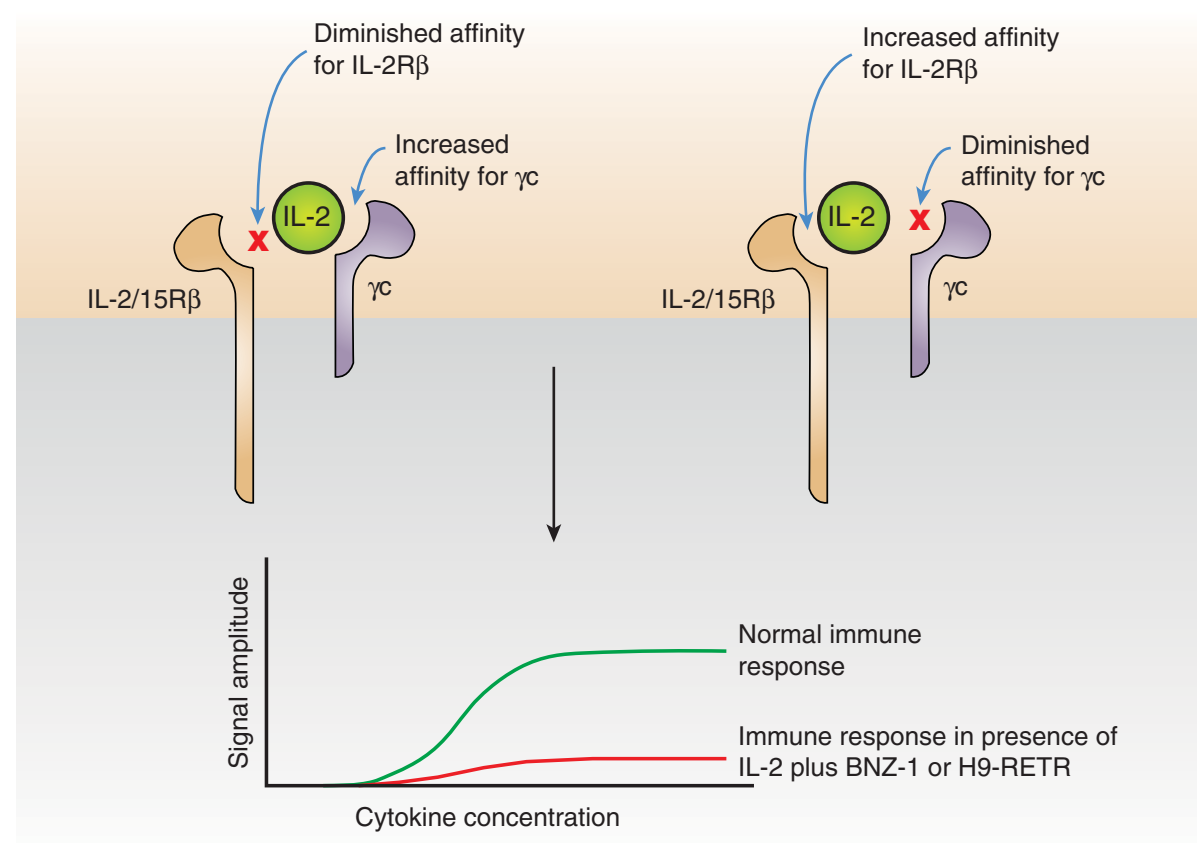

Figure 5. Modified interleukin (IL)-2 to simultaneously inhibit IL-2 and IL-15 action. Two modifications of IL-2 have been generated that block binding of normal IL-2 and IL-15 to IL-2/IL-15R $\beta$ and $\gamma$ chain $(\gamma c)$, thereby simultaneously inhibiting the actions of both IL-2 and IL-15. BNZ-1 (left) binds only to the $\gamma c$ but not IL-2/IL$15 R \beta$ (Nata et al. 2015). In parallel, the RETR mutant of H9 superkine IL-2 (H9-RETR, right) binds tightly to IL2/IL-15R $\beta$ but not $\gamma c$ (Mitra et al. 2015). Both agents prevent the heterodimerization of IL-2R $\beta$ with $\gamma c$, which is required for signaling.

IFNs, in addition to $\gamma c$ cytokines. JAK3 is an alternative attractive target because its expression is restricted to cells of the hematopoietic lineage and is exclusively associated with the common $\gamma$ chain. Mutations of JAK3 in humans or mice resulted in abnormalities restricted to SCID (Noguchi et al. 1993; Macchi et al. 1995; Russell et al. 1995; Liao et al. 2011b).

Nevertheless, Haan and coworkers (2011) have reported that JAK1 has a dominant role over JAK3 in signal transduction through $\gamma \mathrm{c}-$ containing cytokine receptors and conclude that a selective adenosine triphosphate (ATP) competitive JAK3 kinase inhibitor would not be effective as a therapeutic agent. In contrast, Smith et al. (2016) showed that a selective covalent inhibitor of JAK3 (JAK3i) blocked IL-2-stimulated proliferation with great selectivity. This observation reflected the temporal disassociation of
IL-2 signaling, whereas JAK3i revealed a basic biphasic role for JAK3 catalytic activity in $\mathrm{CD}_{4}^{+}$ T cells. The JAK3i blocked a second wave of IL-2mediated signaling. Thus, the results of Smith et al. contradict the conclusions of Haan et al. and reveal the preferential requirement for JAK3 kinase activity in a second wave of IL-2-mediated signaling, indicating that it would be a very attractive target in the treatment of T-cell malignancy.

\section{CONCLUSIONS AND FUTURE DIRECTIONS}

Cytokines play pivotal roles in the actions of the innate and adaptive immune system that normally are directed toward eliminating invading pathogens and the prevention of the development of neoplasia. Cytokines acting in autocrine and paracrine fashion regulate the immune system and play important roles in the control of 
this system. Currently, IFN- $\alpha$, IFN- $\beta$, IL-2, and GM-GSF are approved for various clinical indications, including anticancer treatment, and others, such as IL-12, IL-15, and IL-21, are undergoing clinical evaluation. Despite efforts to develop systemic monotherapy with cytokines for cancer, this approach has several limitations that must be overcome for cytokines to play a dominant role in the immunotherapy of cancer. There is a failure to achieve adequate concentrations of cytokines at the immune cells in the tumor bed. To address this limitation, antibody cytokine fusion proteins have been generated to deliver the cytokine primarily to the tumor bed. Also, the cytokines often elicit immune checkpoints; for example, IL-2 stimulates the survival of Tregs. One strategy that has been used is genetic engineering to modify the IL- 2 molecule so that it binds tightly to the $\beta$ and $\gamma$ chain and does not require the presence of the $\alpha$ chain that is expressed by Tregs. An alternative strategy might be to use IL-2 with an antibody to CCR4 (e.g., mogamulizumab) that is expressed predominantly by Tregs among normal cells. A limitation of GM-CSF is the elicitation of granulocyte-suppressive cells. Most of the cytokines, including $\gamma$ cytokines, rapidly elicit the intracellular expression of one of the eight SOCS family of proteins that dephosphorylate JAKs and STATs (Sckisel et al. 2015). This yields inadequate helper CD4 cells yielding "helpless" antigen-nonspecific CD8 T cells. In the case of IL-15, this is being addressed by the administration of IL-15 with anti-CD40 that eliminates the requirement for CD4 helper cells (Sckisel et al. 2015). Cytokines such as IL-2 and especially IL-15 dramatically augment the number and state of activation of NK cells. However, the action of these cells is aborted by the interaction of an inhibitory KIR and NKG2A receptor with self-class $1 \mathrm{MHC}$ and A or B and E, respectively, which is expressed on the tumor cells. To address this impediment, cytokines, including IL-15, are being coadministered with antitumor monoclonal antibodies to augment the NK-mediated ADCC of the anticancer monoclonal antibodies.

It is hoped that with novel combination approaches, cytokines will ultimately play a major role in cancer immunotherapy.

\section{ACKNOWLEDGMENTS}

This work is supported by the Intramural Research Program of the National Cancer Institute, Center for Cancer Research, National Institutes of Health.

\section{REFERENCES}

Alexander WS, Hilton DJ. 2004. The role of suppressors of cytokine signaling (SOCS) proteins in regulation of the immune response. Annu Rev Immunol 22: 503-529.

Amato R. 1999. Modest effect of interferon $\alpha$ on metastatic renal-cell carcinoma. Lancet 353: 6-7.

Ardolino M, Hsu J, Raulet DH. 2015. Cytokine treatment in cancer immunotherapy. Oncotarget 6: 19346-19347.

Atkins MB, Lotze MT, Dutcher JP, Fisher RI, Weiss G, Margolin K, Abrams J, Sznol M, Parkinson D, Hawkins M, et al. 1999. High-dose recombinant interleukin-2 therapy for patients with metastatic melanoma: Analysis of 270 patients treated between 1985 and 1993. J Clin Oncol 17: 2105-2116.

Bamford RN, DeFilippis AP, Azimi N, Kurys G, Waldmann TA. 1998. The $5^{\prime}$ untranslated region, signal peptide and the coding sequence of the carboxyl terminus of IL-15 participate in its multifaceted translation control. J Immunol 160: 4418-4426.

Bazarbachi A, Plumelle Y, Ramos JC, Tortevoye P, Otrock Z, Taylor G, Gessain A, Harrington W, Panelatti G, Hermine O. 2010. Meta-analysis on the use of zidovudine and interferon- $\alpha$ in adult T-cell leukemia/lymphoma showing improved survival in the leukemic subtypes. J Clin Oncol 28: $4177-4183$.

Becker JC, Varki N, Gillies SD, Furukawa K, Reisfeld RA. 1996. An antibody-interleukin 2 fusion protein overcomes tumor heterogeneity by induction of a cellular immune response. Proc Natl Acad Sci 93: 7826-7831.

Bennett SRM, Carbone FR, Karamalis F, Flavell RA, Miller JFAP, Heath WR. 1998. Help for cytotoxic-T-cell responses is mediated by CD40 signalling. Nature 393: $478-480$

Berger C, Berger M, Hackman RC, Gough M, Elliott C, Jensen MC, Riddell SR. 2009. Safety and immunologic effects of IL-15 administration in nonhuman primates. Blood 114: 2417-2426.

Berkowitz JL, Janik JE, Stewart DM, Jaffe ES, Stetler-Stevenson M, Shih JH, Fleisher TA, Turner M, Urquhart NE, Wharfe GH, et al. 2014. Safety, efficacy, and pharmacokinetics/pharmacodynamics of daclizumab (anti-CD25) in patients with adult T-cell leukemia/lymphoma. Clin Immunol 155: 176-187.

Bessard A, Sole V, Bouchaud G, Quemener A, Jacques Y. 2009. High antitumor activity of RLI, an interleukin-15 (IL-15)-IL-15 receptor $\alpha$ fusion protein, in metastatic melanoma and colorectal cancer. Mol Cancer Ther 8: 2736-2745.

Bhatia S, Curti B, Ernstoff MS, Gordon M, Heath EI, Miller WH Jr, Puzanov I, Quinn DI, Flaig TW, VanVeldhuizen P, et al. 2014. Recombinant interleukin-21 plus sorafenib 
for metastatic renal cell carcinoma: A phase $1 / 2$ study. $J$ Immunother Cancer doi: 10.1186/2051-1426-2-2.

Boder ET. 2012. Protein engineering: Tighter ties that bind. Nature 484: 463-464.

Boyman O, Sprent J. 2012. The role of interleukin-2 during homeostasis and activation of the immune system. Nat Rev Immunol 12: 180-190.

Boyman O, Kovar M, Rubinstein MP, Surh CD, Sprent J. 2006. Selective stimulation of T cell subsets with antibody-cytokine immune complexes. Science 311: 19241927.

Brideau-Andersen AD, Huang XJ, Sun SCC, Chen TT, Stark D, Sas IJ, Zadik L, Dawes GN, Guptill DR, McCord R, et al. 2007. Directed evolution of gene-shuffled IFN- $\alpha$ molecules with activity profiles tailored for treatment of chronic viral diseases. Proc Natl Acad Sci 104: 8269-8274.

Caligiuri MA, Murray C, Robertson MJ, Wang E, Cochran K, Cameron C, Schow P, Ross ME, Klumpp TR, Soiffer RJ, et al. 1993. Selective modulation of human natural killer cells in vivo after prolonged infusion of low dose recombinant interleukin 2. J Clin Invest 91: 123-132.

Cappuccio A, Elishmereni M, Agur Z. 2006. Cancer immunotherapy by interleukin-21: Potential treatment strategies evaluated in a mathematical model. Cancer Res 66: 7293-7300.

Carson WE, Giri JG, Lindemann MJ, Linett ML, Ahdieh M, Paxton R, Anderson D, Eisenmann J, Grabstein K, Caligiuri MA. 1994. Interleukin (IL)-15 is a novel cytokine that activates human natural-killer-cells via components of the IL-2 receptor. J Exp Med 180: 1395-1403.

Carson WE, Fehniger TA, Haldar S, Eckhert K, Lindemann MJ, Lai CF, Croce CM, Baumann H, Caligiuri MA. 1997. Potential role for interleukin-15 in the regulation of human natural killer cell survival. J Clin Invest 99: 937-943.

Carter P. 2001. Improving the efficacy of antibody-based cancer therapies. Nat Rev Cancer 1: 118-129.

Chan SH, Kobayahi M, Santoli D, Perussia B, Trinchieri G. 1992. Mechanisms of IFN- $\gamma$ induction by natural killer cell stimulatory factor (NKSF/IL-12). Role of transcriptions and mRNA stability in the synergistic interaction between NKSF and IL-2. J Immunol 148: 92-98.

Chen J, Petrus M, Bryant BR, Nguyen VP, Stamer M, Goldman CK, Bamford R, Morris JC, Janik JE, Waldmann TA. 2008. Induction of the IL-9 gene by HTLV-1 Tax stimulates the spontaneous proliferation of primary adult $\mathrm{T}$-cell leukemia cells by a paracrine mechanism. Blood 111: 5163-5172.

Chen J, Petrus M, Bamford R, Shih JH, Morris JC, Janik JE, Waldmann TA. 2012a. Increased serum soluble IL-15R $\alpha$ levels in T-cell large granular lymphocyte leukemia. Blood 119: $137-143$.

Chen E, Staudt LM, Green AR. 2012b. Janus kinase deregulation in leukemia and lymphoma. Immunity 36: 529541.

Chertova E, Bergamaschi C, Chertov O, Sowder R, Bear J, Roser JD, Beach RK, Lifson JD, Felber BK, Pavlakis GN. 2013. Characterization and favorable in vivo properties of heterodimeric soluble IL-15.IL-15R $\alpha$ cytokine compared to IL-15 monomer. J Biol Chem 288: 18093-18103.

Chronic Myeloid Leukemia Trialists' Collaborative Group. 1997. Interferon $\alpha$ versus chemotherapy for chronic my- eloid leukemia: A meta-analysis of seven randomized trials. J Natl Cancer Inst 89: 1616-1620.

Conlon KC, Lugli E, Welles HC, Rosenberg SA, Fojo AT, Morris JC, Fleisher TA, Dubois SP, Perera LP, Stewart DM, et al. 2015. Redistribution, hyperproliferation, activation of natural killer cells and CD8 T cells, and cytokine production during first-in-human clinical trial of recombinant human interleukin-15 in patients with cancer. $J$ Clin Oncol 33: 74-82.

Constantinescu SN, Croze E, Wang C, Murti A, Basu L, Mullersman JE, Pfeffer LM. 1994. Role of interferon $\alpha / \beta$ receptor chain 1 in the structure and transmembrane signaling of the interferon $\alpha / \beta$ receptor complex. Proc Natl Acad Sci 91: 9602-9606.

Crescenzo R, Abate F, Lasorsa E, Tabbo F, Gaudiano M, Chiesa N, Di Giacomo F, Spaccarotella E, Barbarossa L, Ercole E, et al. 2015. Convergent mutations and kinase fusions lead to oncogenic STAT3 activation in anaplastic large cell lymphoma. Cancer Cell 27: 516-532.

Damjanovich S, Bene L, Matko J, Alileche A, Goldman CK, Sharrow S, Waldmann TA. 1997. Preassemably of interleukin 2 (IL-2) receptor subunits on resting Kit $225 \mathrm{~K} 6 \mathrm{~T}$ cells and their modulation by IL-2, IL-7, and IL-15: A fluorescence resonance energy transfer study. Proc Natl Acad Sci 94: 13134-13139.

Dobbeling U, Dummer R, Laine E, Potoczna N, Gin JZ, Burg G. 1998. Interleukin-15 is an autocrine/paracrine viability factor for cutaneous T-cell lymphoma cells. Blood 92: 252-258.

Dranoff G. 2002. GM-CSF-based cancer vaccines. Immunol Rev 188: 147-154.

Dranoff G. 2004. Cytokines in cancer pathogenesis and cancer therapy. Nat Rev Cancer 4: 11-22.

Dranoff G, Jaffee E, Lazenby A, Golumbek P, Levitsky H, Brose K, Jackson V, Hamada H, Pardoll D, Mulligan RC. 1993. Vaccination with irradiated tumor cells engineered to secrete murine granulocyte-macrophage colony-stimulating factor stimulates potent, specific, and long-lasting anti-tumor immunity. Proc Natl Acad Sci 90: 3539-3543.

Dubois S, Mariner J, Waldmann TA, Tagaya Y. 2002. IL$15 R \alpha$ recycles and presents IL-15 in trans to neighboring cells. Immunity 17: 537-547.

Dubois S, Patel HJ, Zhang M, Waldmann TA, Muller JR. 2008. Preassociation of IL-15 with IL-15R $\alpha$-IgG1-Fc enhances its activity on proliferation of $\mathrm{NK}$ and $\mathrm{CD}^{+} /$ CD44 $4^{\text {high }} \mathrm{T}$ cells and its antitumor action. J Immunol 180: 2099-2106.

Dutcher JP, Schwartzentruber DJ, Kaufman HL, Agarwala SS, Tarhini AA, Lowder JN, Atkins MB. 2014. High dose interleukin-2 (Aldesleukin): Expert consensus on best management practices-2014. J ImmunoTherapy Cancer 2: 26 .

Evans R, Fuller JA, Christianson G, Krupke DM, Trout AB. 1997. IL-15 mediates anti-tumor effects after cyclophosphamide injection of tumor-bearing mice and enhances adoptive immunotherapy: The potential role of NK cell subpopulations. Cell Immunol 179: 66-73.

Fehniger TA, Caligiuri MA. 2001. Interleukin-15: Biology and relevance to human disease. Blood 97: 14-32.

Fehniger TA, Bluman EM, Porter MM, Mrózek E, Cooper MA, VanDeusen JB, Frankel SR, Stock W, Caligiuri MA 2000. Potential mechanisms of human natural killer cell 
T.A. Waldmann

expansion in vivo during low-dose IL-2 therapy. J Clin Invest 106: 117-124.

Fehniger TA, Cooper MA, Caligiuri MA. 2002. Interleukin-2 and interleukin-15: Immunotherapy for cancer. Cytokine Growth Factor Rev 13: 169-183.

Ferrari-Lacraz S, Zheng XX, Kim YS, Li YS, Maslinski W, Li XC, Strom TB. 2001. An antagonist IL-15/Fc protein prevents costimulation blockade-resistant rejection. J Immunol 167: 3478-3485.

Ferrari-Lacraz S, Zanelli E, Neuberg M, Donskoy E, Kim YS, Zheng XX, Hancock WW, Maslinski W, Li XC, Strom TB, et al. 2004. Targeting IL-15 receptor-bearing cells with an antagonist mutant IL-15/Fc protein prevents disease development and progression in murine collagen-induced arthritis. J Immunol 173: 5818-5826.

Flanigan RC, Salmon SE, Blumenstein BA, Bearman SI, Roy V, McGrath PC, Caton JR Jr, Nikhil M, Crawford ED. 2001. Nephrectomy followed by interferon $\alpha-2 b$ compared with interferon $\alpha-2 b$ alone for metastatic renalcell cancer. N Eng J Med 345: 1655-1659.

Fyfe G, Fisher RI, Rosenberg SA, Sznol M, Parkinson DR, Louie AC. 1995. Results of treatment of 255 patients with metastatic renal cell carcinoma who received high-dose recombinant interleukin-2 therapy. J Clin Oncol 13: 688696.

Goldman JM, Marin D, Olavarria E, Apperley JF. 2003. Clinical decisions for chronic myeloid leukemia in the imatinib era. Semin Hemtol 40: 98-103.

Goldstein D, Laszio J. 1988. The role of interferon in cancer therapy: A current perspective. CA Cancer J Clin 38: 258277.

Gollob JA, Mier JW, Veenstra K, McDermott DF, Clancy D, Clancy M, Atkins MB. 2000. Phase I trial of twice-weekly intravenous interleukin 12 in patients with metastatic renal cell cancer or malignant melanoma: Ability to maintain IFN- $\gamma$ induction is associated with clinical response. Clin Cancer Res 6: 1678-1692.

Gupta R, Emens LA. 2010. GM-CSM-secreting vaccines for solid tumors: Moving forward. Discov Med 10: 52-60.

Gutterman JU, Blumenschein GR, Alexanian R, Yap HY, Budzdar AU, Cabanillas F, Hortobagyi GN, Hersh EM, Rasmussen SL, Harmon M, et al. 1980. Leukocyte interferon-induced tumor regression in human metastatic breast cancer, multiple myeloma and malignant lymphoma. Ann Intern Med 93: 399-406.

Haan C, Rolvering C, Raulf F, Kapp M, Druckes P, Thoma G, Behrmann I, Zerwes HG. 2011. Jak1 has a dominant role over Jak3 in signal transduction through $\gamma \mathrm{c}$-containing cytokine receptors. Chem Biol 18: 314-323.

Isaacs A, Lindenmann J. 2015. Virus interference. I: The interferon. J Immunol 195: 1911-1920.

Jain S, Chen J, Nicolae A, Wang H, Shin DM, Adkins EB, Sproule TJ, Leeth CM, Sakai T, Kovalchuk AL, et al. 2015. IL-21 driven neoplasms in SJL mice mimic some key features of human angioimmunoblastic T-cell lymphoma. Am J Pathol 185: 3102-3114.

Jin GH, Hirano T, Murakami M. 2008. Combination treatment with IL-2 and anti-IL-2 mAbs reduces tumor metastasis via NK cell activation. Int Immunol 20: 783-789.

Ju W, Zhang ML, Jiang JK, Thomas CJ, Oh U, Bryant BR, Chen J, Sato N, Tagaya Y, Morris JC, et al. 2011. CP-
690,550, a therapeutic agent, inhibits cytokine-mediated Jak 3 activation and proliferation of T cells from patients with ATL and HAM/TSP. Blood 117: 1938-1946.

Kaufman HL, Ruby CE, Hughes T, Slingluff CL Jr. 2014. Current status of ganulocyte-macrophage colony-stimulating factor in the immunotherapy of melanoma. J Immunother Cancer doi: 10.1186/2051-1426-2-11.

Kennedy MK, Glaccum M, Brown SN, Butz EA, Viney JL, Embers M, Matsuki N, Charrier K, Sedger L, Willis CR, et al. 2000. Reversible defects in natural killer and memory CD8 T cell lineages in interleukin 15-deficient mice. J Exp Med 191: 771-780.

Kirkwood JM, Ernstoff MS. 1984. Interferons in the treatment of human cancer. J Clin Oncol 2: 336-352.

Kirkwood JM, Strawderman MH, Ernstoff MS, Smith TJ, Bordern EC, Blum RH. 1996. Interferon $\alpha$ - $2 \mathrm{~b}$ adjuvant therapy of high-risk resected cutaneous melanoma: The Eastern Cooperative Oncology Group Trial EST 1684. J Clin Oncol 14: 7-17.

Kirkwood JM, Ibrahim JG, Sosman JA, Sondak VK, Agarwala SS, Ernstoff MS, Rao U. 2001. High-dose interferon $\alpha-2 b$ significantly prolongs relapse-free and overall survival compared with the GM2-KLH/QS-21 vaccine in patients with resected stage IIB-III melanoma: Results of intergroup trial E1694/S9512/C509801. J Clin Oncol 19: $2370-2380$.

Klebanoff CA, Finkelstein SE, Surman DR, Lichtman MK, Gattinoni L, Theoret MR, Grewal N, Spiess PJ, Antony PA, Palmer DC, et al. 2004. Il-15 enhances the in vivo antitumor activity of tumor-reactive $\mathrm{CD}^{+} \mathrm{T}$ cells. Proc Natl Acad Sci 101: 1969-1974.

Kobayashi H, Dubois S, Sato N, Sabzevari H, Sakai Y, Waldmann TA, Tagaya Y. 2005. Role of trans-cellular IL-15 presentation in the activation of NK cell-mediated killing, which leads to enhanced tumor immunosurveillance. Blood 105: 721-727.

Koskela HLM, Eldfors S, Ellonen P, van Adrichem AJ, Kuusanmaki H, Andersson EI, Lagstrom S, Clemente MJ, Olson T, Jalkanen SE, et al. 2012. Somatic STAT3 mutations in large granular lymphocytic leukemia. $N$ Engl J Med 366: 1905-1913.

Kucuk C, Jiang B, Hu XZ, Zhang WY, Chan JKC, Xiao WM, Lack N, Alkan C, Williams JC, Avery KN, et al. 2015. Activating mutations of STAT5B and STAT3 in lymphomas derived from $\gamma \delta$-T or NK cells. Nat Commun doi: $10.1038 /$ ncomms7025.

Lange F, Rateitschak K, Fitzner B, Pöhland R, Wolkenhauer O, Jaster R. 2011. Studies on mechanisms of interferon- $\gamma$ action in pancreatic cancer using a data-driven and model-based approach. Mol Cancer doi: 10.1186/1476-459810-13.

Lasek W, Zagozdzon R, Jakobisiak M. 2014. Interleukin 12: Still a promising candidate for tumor immunotherapy? Cancer Immunol Immunother 63: 419-435.

Lee S, Margolin K. 2011. Cytokines in cancer immunotherapy. Cancers 3: 3856-3893.

Leonard WJ, O’Shea JJ. 1998. Jaks and STATs: Biological implications. Annu Rev Immunol 16: 293-322.

Leonardo MJ. 1996. Fas and the art of lymphocyte maintenance. J Exp Med 183: 721-724. 
Leroy S, Dubois S, Tenaud I, Chebassier N, Godard A, Jacques Y, Dreno B. 2001. Interleukin-15 expressions in cutaneous T-cell lymphoma (mycosis fungoides and Sézary syndrome). Br J Dematol 144: 1016-1023.

Levin AM, Bates DL, Ring AM, Krieg C, Lin JT, Su L, Moraga I, Raeber ME, Bowman GR, Novick P, et al. 2012. Exploiting a natural conformational switch to engineer an interleukin-2 "superkine." Nature 484: 529-533.

Li B, Lalani AS, Harding TC, Luan B, Koprivnikar K, Tu GH, Prell R, VanRoey MJ, Simons AD, Jooss K. 2006. Vascular endothelial growth factor blockade reduces intratumoral regulatory T cells and enhances the efficacy of a GM-CSFsecreting cancer immunotherapy. Clin Cancer Res 12: 6808-6816.

Liao W, Lin JX, Leonard WJ. 2011a. IL-2 family cytokines: New insights into the complex roles of IL-2 as a broad regulator of T helper cell differentiation. Curr Opin Immunol 23: 598-604.

Liao W, Lin JX, Wang L, Li P, Leonard WJ. 2011b. Modulation of cytokine receptors by IL-2 broadly regulates differentiation into helper T cell lineages. Nat Immunol 12: 551-559.

Lode HN, Reisfield RA. 2000. Targeted cytokines for cancer immunotherapy. Immunol Res 21: 279-288.

Lugli E, Goldman CK, Perera LP, Smedley J, Pung R, Yovandich JL, Jason L, Creekmore SP, Waldmann TA, Roederer M. 2010. Transient and persistent effects of IL-15 on lymphocyte homeostasis in nonhuman primates. Blood 116: 3238-3248.

Ma HL, Whitters MJ, Konz RF, Senices M, Young DA, Grusby MJ, Collins M, Dunussi-Joannopoulos K. 2003. IL-21 activates both innate and adaptive immunity to generate potent antitumor responses that require perforin but are independent of IFN- $\gamma$. J Immunol 171: 608-615.

Macchi P, Villa A, Giliani S, Sacco MG, Frattini A, Porta F, Ugazio AG, Johnston JA, Candotti F, O'Shea JJ, et al. 1995. Mutations of $J A K-3$ gene in patients with autosomal severe combined immune-deficiency (SCID). Nature 377: 6544-6568.

Mach N, Dranoff G. 2000. Cytokine-secreting tumor cell vaccines. Curr Opin Immunol 12: 571-575.

Marks-Konczalik J, Dubois S, Losi JM, Sabzevari H, Yamada N, Feigenbaum L, Waldmann TA, Tagaya Y. 2000. IL-2induced activation-induced cell death is inhibited in IL15 transgenic mice. Proc Natl Acad Sci 97: 11445-11450.

Migone JX, Cereseto A, Mulloy JC, O'Shea JJ, Franchini G, Leonard WJ. 1995. Constitutively activated Jak-STAT pathways in T-cells transformed with HTLV-1. Science 269: 79-81.

Mishra A, Kwiatkowski S, Sullivan L, Grinshpun L, Russo G, Porcu P, Caligiuri M. 2015. Epigenetic disruption of ZEB1 binding causes constructive activation of IL-15 in cutaneous T-cell lymphoma. Blood 126: 2 .

Mitra S, Ring AM, Amarnath S, Spangler JB, Li P, Ju W, Fischer S, Oh J, Spolski R, Weiskopf K, et al. 2015. Interleukin-2 activity can be fine tuned with engineered receptor signaling clamps. Immunity 42: 826-838.

Moga E, Alvareza E, Canto E, Vidal S, Rodriguez-Sanchez JL, Sierra J, Briones J. 2008. NK cells stimulated with IL-15 or CpG ODN enhance rituximab-dependent cellular cytotoxicity against B-cell lymphoma. Exp Hematol 36: 6977.
Mortier E, Quemener A, Vusio P, Lorenzen I, Boublik Y, Grotzinger J, Plet A, Jacques Y. 2006. Soluble interleukin-15 receptor $\alpha(\mathrm{IL}-15 \mathrm{R} \alpha)$-sushi as a selective and potent agonist of IL-15 action through IL-15R $\beta / \gamma$-Hyperagonist IL-15-IL-15R $\alpha$ fusion proteins. J Biol Chem 281: 1612-1619.

Mortier E, Woo T, Advincula R, Gozalo S, Ma A. 2008. IL$15 R \alpha$ chaperones IL-15 to stable dendritic cell membrane complexes that activate NK cells via trans presentation. J Exp Med 205: 1213-1225.

Mueller YM, Petrovas C, Bojczuk PM, Dimitriou LD, Beer B, Silvera P, Villinger F, Cairns JS, Gracely EJ, Lewis MG, et al. 2005. Interleukin- 15 increases effector memory CD $8^{+}$ $\mathrm{T}$ cells and NK cells in simian immunodeficiency virusinfected macaques. J Virol 79: 4877-4885.

Muller M, Ibelgaufts H, Kerr IM. 1994a. Interferon response pathways-A paradigm for cytokine signaling? J Viral Hepat 1: 87-103.

Muller U, Steinhoff U, Reis LFL, Hemmi S, Pavlovic J, Zinkernagel RM, Aguet M. 1994b. Functional-role of type-I and type-II interferons in antiviral defense. Science 264: 1918-1921.

Munger W, Dejoy SQ, Jeyaseelan R, Torley LW, Grabstein KH, Eisenmann J, Paxton R, Cox T, Wick MM, Kerwar SS. 1995. Studies evaluating the antitumor-activity and toxicity of interleukin-15, a new T-cell growth-factorComparison with interleukin-2. Cell Immunol 165: 289293.

Nakahata S, Yamazaki S, Nakauchi H, Morishita K. 2010. Downregulation of ZEB1 and overexpression of Smad7 contribute to resistance to TGF- $\beta$-mediated growth suppression in adult T-cell leukemia/lymphoma. Oncogene 29: 4157-4169.

Nata T, Basheer A, Cocchi F, van Besien R, Massoud R, Jacobson S, Azimi N, Tagaya Yl. 2015. Targeting the binding interface on a shared receptor subunit of a cytokine family enables the inhibition of multiple member cytokines with selectable target spectrum. J Biol Chem 290: 22338-22351.

Nicholas C, Lesinski GB. 2011. Immunomodulatory cytokines as therapeutic agents for melanoma. Immunotherapy 3: 673-690.

Noguchi M, Yi HF, Rosenblatt HM, Flipovich AH, Adelstein S, Modi WS, Mcbride OW, Leonard WJ. 1993. Interleukin-2 receptor $\gamma$ chain mutation results in X-linked severe combined immunodeficiency in humans. Cell 73: 147157.

O'Shea JJ, Holland SM, Staudt LM. 2013. Review article mechanism of disease. JAKS and STATs in immunity, immunodeficiency, and cancer. $N$ Engl J Med 368: 161170.

Penichet ML, Morrison SL. 2001. Antibody-cytokine fusion proteins for the therapy of cancer. J Immunol Methods 248: 91-101.

Pettit DK, Bonnert TP, Eisenman J, Srinivasan S, Paxton R, Beers C, Lynch D, Miller B, Yost J, Grabstein KH, et al. 1997. Structure-function studies of interleukin 15 using site-specific mutagenesis, polyethylene glycol conjugation, and homology modeling. J Biol Chem 272: 2312 2318.

Pharmaceutical Business Review. 2013. Altor launches clinical trial of IL-15 superagonist protein complex against 
T.A. Waldmann

metastatic melanoma. clinicaltrials.pharmaceutical-busi ness-review.com/news/altor-launches-clinical-trial-of-il15-superagonist-protein-complex-against-metastatic-me lanoma-190813.

Quesada JR, Talpaz M, Rios A, Kurzrock R, Gutterman JU. 1986. Clinical toxicity of interferons in cancer patients: A review. J Clin Oncol 4: 234-243.

Ratain MJ, Golomb HM, Vardiman JW, Vokes EE, Jacobs RH, Daly K. 1985. Treatment of hairy-cell leukemia with recombinant $\alpha-2$ interferon. Blood 65: 644-648.

Reisfeld RA, Gillies SD. 1996. Antibody-interleukin 2 fusion proteins: A new approach to cancer therapy. J Clin Lab Anal 10: 160-166.

Ridge JP, Di Rosa F, Matzinger P. 1998. A conditioned dendritic cell can be a temporal bridge between a $\mathrm{CD} 4^{+} \mathrm{T}$ helper and a T-killer cell. Nature 393: 474-478.

Roberti MP, Barrio MM, Bravo Al, Rocca YS, Arriaga JM, Bianchini M, Mordoh J, Levy EM. 2011. IL-15 and IL-2 increase cetuximab-mediated cellular cytotoxicity against triple negative breast cancer cell lines expressing EGFR. Breast Cancer Res Treat 130: 465-575.

Rochman R, Leonard WJ. 2009. New insights into the regulation of T cells by $\gamma_{c}$ family cytokines. Nat Rev Immunol 9: 480-490.

Rosenberg SA, Lotze MT, Yang JC, Aebersold PM, Linehan WM, Seipp CA, White DE. 1989. Experience with the use of high-dose interleukin-2 in the treatment of 652 cancerpatients. Ann Surg 210: 474-485.

Roychowdhury S, May KF Jr, Tzou KS, Lin T, Bhatt D, Freud AG, Guimond M, Ferketich AK, Liu Y, Caligiuri MA. 2004. Failed adoptive immunotherapy with tumor-specific T cells: Reversal with low-dose interleukin 15 but not low-dose interleukin 2. Cancer Res 64: 8062-8067.

Russell SM, Tayebi N, Nakajima H, Riedy MC, Roberts JL Aman MJ, Migone TS, Noguchi M, Markert ML, Buckley $\mathrm{RH}$, et al. 1995. Mutation of JAK3 in a patient with SCID essential role of JAK3 in lymphoid development. Science 270: $797-800$.

Sadlack B, Kuhn R, Schorle H, Rajewsky K, Muller W, Horak I. 1994. Development and proliferation of lymphocytes in mice deficient for both interleukin-2 and interleukin-4. Eur J Immunol 24: 281-284.

Sakaguchi S, Sakaguchi N, Asano M, Itoh M, Toda M. 1995. Immunological self-tolerance maintained by activated $\mathrm{T}$ cells expressing Il-2 receptor $\alpha$-chains (CD25)-Breakdown of a single mechanism of self-tolerance causes various autoimmune diseases. J Immunol 155: 1151-1164.

Schluns KS, Klonowski KD, Lefrancois L. 2004. Transregulation of memory CD8 T-cell proliferation by IL-15R $\alpha^{+}$ bone marrow-derived cells. Blood 103: 988-994.

Schoenberger SP, Toes REM, van der Voort EIH, Offringa R, Melief CJM. 1998. T-cell help for cytotoxic T lymphocytes is mediated by CD40-CD40L interactions. Nature 393: 480-483.

Schrama D, Reisfeld RA, Becker JC. 2006. Antibody targeted drugs as cancer therapeutics. Nat Rev Drug Discov 5: 147 159.

Sckisel GD, Bouchlaka MN, Monjazeb AM, Crittenden M, Curti BD, Wilkins DEC, Alderson KA, Sungur CM, Ames E, Mirsoian A, et al. 2015. Out-of-sequence signal 3 par- alyzes primary $\mathrm{CD} 4^{+} \mathrm{T}$-cell-dependent immunity. Immunity 43: 240-250.

Skak K, Kragh M, Hausman D, Smyth MJ, Sivakumar PV. 2008. Interleukin 21: Combination strategies for cancer therapy. Nat Rev Drug Discov 7: 231-240.

Smith GA, Uchida K, Weiss A, Taunton J. 2016. Essential biphasic role for JAK3 catalytic activity in IL-2 receptor signaling. Nat Chem Biol 12: 373.

Sneller MC, Kopp WC, Engelke KJ, Yovandich JL, Creekmore SP, Waldmann TA, Lane HC. 2011. IL-15 administered by continuous infusion to rhesus macaques induces massive expansion of $\mathrm{CD}^{+} \mathrm{T}$ effector memory population in peripheral blood. Blood 118: 6845-6848.

Soiffer RJ, Murray C, Cochran K, Cameron C, Wang E, Schow PW, Daley JF, Ritz J. 1992. Clinical and immunological effects of prolonged infusion of low-dose recombinant interleukin-2 after autologous and T-cell depleted allogeneic bone-marrow transplantation. Blood 79: 517526.

Soiffer RJ, Murray C, Shapiro C, Collins H, Chartier S, Lazo S, Ritz J. 1996. Expansion and manipulation of natura killer cells in patients with metastatic cancer by low-dose continuous infusion and intermittent bolus administration of interleukin 2. Clin Cancer Res 2: 493-499.

Sondel PM, Hank JA. 1997. Combination therapy with interleukin-2 and antitumor monoclonal antibodies. Cancer J Sci Am 3: S121-S127.

Spangler JB, Moraga I, Mendoza JL, Garcia KC. 2015. Insights into cytokine-receptor interactions from cytokine engineering. Annu Rev Immunol 33: 139-167.

Spolski R, Leonard WJ. 2008. Interleukin-21: Basic biology and implications for cancer and autoimmunity. Annu Rev Immunol 26: 57-79.

Spolski R, Leonard WJ. 2014. Interleukin-21: A doubleedged sword with therapeutic potential. Nat Rev Drug Discov 13: 379-395.

Steel JC, Waldmann TA, Morris JC. 2012. Interleukin-15 biology and its therapeutic implications in cancer. Trends Pharmacol Sci 33: 35-41.

Steele N, Anthony A, Saunders M, Esmarck B, Ehmrooth E, Kristjansen PEG, Nihlen A, Hansen LT, Cassidy J. 2012. A phase 1 trial of recombinant human IL-21 in combination with cetuximab in patients with metastatic colorectal cancer. Br J Cancer 106: 793-798.

Stemmer WPC. 1994. Rapid evolution of a protein in-vitro by DNA shuffling. Nature 370: 389-391.

Tagliaferri P, Caraglia M, Budillon A, Marra M, Vitale G, Viscomi C, Masciari S, Tassone P, Abbruzzese A, Venuta S. 2005. New pharmacokinetic and pharmacodynamic tools for interferon- $\alpha$ (IFN- $\alpha$ ) treatment of human cancer. Cancer Immunol Immunother 54: 1-10.

Taniguchi T, Minami Y. 1993. The IL-2/IL-2 receptor system-A current overview. Cell 73: 5-8.

Tendler CL, Greenberg SJ, Blattner WA, Manns A, Murphy E, Fleisher T, Hanchard B, Morgan O, Burton JD, Nelson DL, et al. 1990. Transactivation of interleukin-2 and its receptor induces immune activation in human $\mathrm{T}$-cell lymphotropic virus type-I associated myelopathy-Pathogenic implications and a rationale for immunotherapy. Proc Natl Acad Sci 87: 5218-5222. 
Timmerman JM, Byrd JC, Andorsky DJ, Yamada RE, Kramer J, Muthusamy N, Hunder N, Pagel JM. 2012. A phase 1 dose-finding trial of recombinant interleukin-21 and rituximab in relapsed and refractory low grade B-cell lymphoproliferative disorders. Clin Cancer Res 18: $5752-$ 5760.

Tinhofer I, Marschitz I, Henn T, Egle A, Greil R. 2000. Expression of functional interleukin-15 receptor and autocrine production of interleukin- 15 as mechanisms of tumor propagation in multiple myeloma. Blood 95: 610618.

Trinchieri G. 1995. Interleukin-12: A proinflammatory cytokine with immunoregulatory functions that bridge innate resistance and antigen-specific adaptive immunity. Annu Rev Immunol 13: 251-276.

Trinchieri G. 2003. Interleukin-12 and the regulation of innate resistance and adaptive immunity. Nat Rev Immunol 3: 133-146.

Vincent M, Teppaz G, Lajoie L, Sole V, Bessard A, Maillasson M, Loisel S, Bechard D, Clemenceau B, Thibault G, et al. 2014. Highly potent anti-CD20-RLI immunocytokine targeting established human B lymphoma in SCID mouse. MABS 6: 1026-1037.

Vincenti F, Kirkman R, Light S, Bumgardner G, Pescovitz M, Halloran P, Neylan J, Wilkinson A, Ekberg H, Gastron R, et al. 1998. Interleukin-2-receptor blockade with daclizumab to prevent acute rejection in renal transplantation. $N$ Engl J Med 338: 161-165.

Waldmann TA. 1986. The structure, function, and expression of interleukin-2 receptors on normal and malignant lymphocytes. Science 232: 727-732.

Waldmann TA. 1991. The interleukin-2 receptor. J Biol Chem 266: 2681-2684

Waldmann TA. 2006. The biology of interleukin-2 and interleukin-15: Implications for cancer therapy and vaccine design. Nat Rev Immunol 6: 595-601.

Waldmann TA. 2007. Anti-Tac (daclizumab, Zenapax) in the treatment of leukemia, autoimmune diseases, and in the prevention of allograft rejection: A 25-year personal odyssey. J Clin Immunol 27: 1-18.

Waldmann TA. 2015. The shared and contrasting roles of IL2 and IL-15 in the life and death of normal and neoplastic lymphocytes: Implications for cancer therapy. Cancer Immunol Res 3: 219-227.

Waldmann TA, Chen J. 2017. Disorders of the JAK/STAT pathway in T-cell lymphoma, pathogenesis: Implications for immunotherapy. Annu Rev Immunol 35: 533-550.

Waldmann TA, Dubois S, Tagaya Y. 2001. Contrasting roles of IL-2 and IL-15 in the life and death of lymphocytes: Implications for immunotherapy. Immunity 14: 105-110.

Waldmann TA, Lugli E, Roederer M, Perera LP, Smedley JV, Macallister RP, Goldman CK, Bryant BR, Decker JM, Fleisher TA, et al. 2011. Safety (toxicity), pharmacokinetics, immunogenicity, and impact on elements of the nor- mal immune system of recombinant human IL-15 in rhesus macaques. Blood 117: 4787-4795.

Waldmann TA, Conlon KC, Stewart DM, Worthy TA, Janik JE, Fleisher TA, Albert PS, Figg WD, Spencer SD, Raffeld M, et al. 2013. Phase 1 trial of IL-15 trans presentation blockade using humanized Mik-B-1 mAb in patients with T-cell large granular lymphocytic leukemia. Blood 121: 476-484.

Wang G, Tschoi M, Spolski R, Lou YY, Ozaki K, Feng CG Kim G, Leonard WJ, Hwu P. 2003. In vivo antitumor activity of interleukin 21 mediated by natural killer cells. Cancer Res 63: 9016-9022.

Wang XQ, Rickert M, Garcia KC. 2005. Structure of the quaternary complex of interleukin-2 with its $\alpha, \beta$, and $\gamma_{c}$ receptors. Science 310: 1159-1163.

Windbichler GH, Hausmaninger H, Stummvoll W, Graf AH, Kainz C, Lahodny J, Denison U, Müller-Holzner E, Marth C. 2000. Interferon- $\gamma$ in the first-line therapy of ovarian cancer: A randomized phase III trial. Br J Cancer 82: 1138-1144.

Young PA, Morrison SL, Timmerman JM. 2014. Antibodycytokine fusion proteins for treatment of cancer: Engineering cytokines for improved efficacy and safety. Semin Oncol 41: 623-636.

Yu P, Steel JC, Zhang ML, Morris JC, Waldmann TA. 2010. Simultaneous blockade of multiple immune system inhibitory checkpoints enhances antitumor activity mediated by interleukin- 15 in a murine metastatic colon carcinoma model. Clin Cancer Res 16: 6019-6028.

Yu P, Steel JC, Zhang ML, Morris JC, Waitz R, Fasso M, Allison JP, Waldmann TA. 2012. Simultaneous inhibition of two regulatory T-cell subsets enhanced interleukin-15 efficacy in a prostate tumor model. Proc Natl Acad Sci 109: 6187-6192.

Zaidi MR, Merlino G. 2011. The two faces of interferon- $\gamma$ in cancer. Clin Cancer Res 17: 6118-6124.

Zeng R, Spolski R, Finkelstein SE, Oh SK, Kovanen PE, Hinrichs CS, Pise-Masison CA, Radonovich MF, Brady JN, Restifo NP, et al. 2005. Synergy of IL-21 and IL-15 in regulating $\mathrm{CD} 8^{+} \mathrm{T}$ cell expansion and function. J Exp Med 201: 139-148.

Zhang ML, Yao ZS, Dubois S, Ju W, Muller JR, Waldmann TA. 2009. Interleukin-15 combined with an anti-CD40 antibody provides enhanced therapeutic efficacy for murine models of colon cancer. Proc Natl Acad Sci 106: 7513-7518.

Zhang ML, Ju W, Yao ZS, Yu P, Wei BR, Simpson RM, Waitz R, Fasso M, Allison JP, Waldmann TA. 2012. Augmented IL-15R $\alpha$ expression by CD40 activation is critical in synergistic CD8 T cell-mediated antitumor activity of antiCD40 antibody with IL-15 in TRAMP-C2 tumors in mice. J Immunol 188: 6156-6164.

Zhu XY, Marcus WD, Xu WX, Lee HI, Han KP, Egan JO, Yovandich JL, Rhode PR, Wong HC. 2009. Novel human interleukin-15 agonists. J Immunol 183: 3598-3607. 


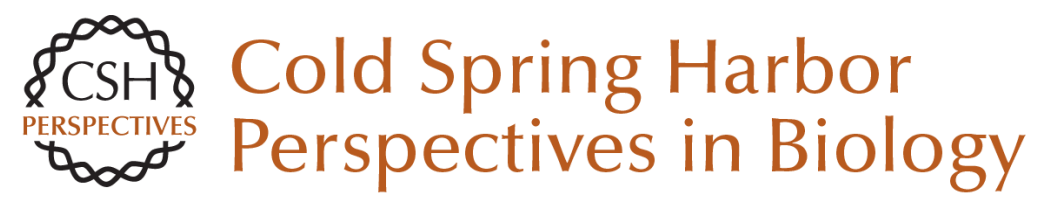

\section{Cytokines in Cancer Immunotherapy}

Thomas A. Waldmann

Cold Spring Harb Perspect Biol 2018; doi: 10.1101/cshperspect.a028472 originally published online November 3, 2017

\section{Subject Collection Cytokines}

Interleukin (IL)-33 and the IL-1 Family of Cytokines --Regulators of Inflammation and Tissue Homeostasis

Ajithkumar Vasanthakumar and Axel Kallies

Targeting IL-10 Family Cytokines for the Treatment of Human Diseases Xiaoting Wang, Kit Wong, Wenjun Ouyang, et al.

Cytokine-Mediated Regulation of CD8 T-Cell Responses During Acute and Chronic Viral Infection

Masao Hashimoto, Se Jin Im, Koichi Araki, et al.

Cytokines in Cancer Immunotherapy

Thomas A. Waldmann

The Tumor Necrosis Factor Family: Family Conventions and Private Idiosyncrasies David Wallach

The Interferon (IFN) Class of Cytokines and the IFN Regulatory Factor (IRF) Transcription Factor Family

Hideo Negishi, Tadatsugu Taniguchi and Hideyuki Yanai
Interferon $\gamma$ and Its Important Roles in Promoting and Inhibiting Spontaneous and Therapeutic Cancer Immunity

Elise Alspach, Danielle M. Lussier and Robert D. Schreiber

Inflammasome-Dependent Cytokines at the Crossroads of Health and Autoinflammatory Disease

Hanne Van Gorp, Nina Van Opdenbosch and Mohamed Lamkanfi

Innate Lymphoid Cells (ILCs): Cytokine Hubs Regulating Immunity and Tissue Homeostasis Maho Nagasawa, Hergen Spits and Xavier Romero Ros

T Helper Cell Differentiation, Heterogeneity, and

Plasticity Jinfang Zhu

Development, Diversity, and Function of Dendritic Cells in Mouse and Human

David A. Anderson III, Kenneth M. Murphy and Carlos G. Briseño

Cytokines and Long Noncoding RNAs Susan Carpenter and Katherine A. Fitzgerald

For additional articles in this collection, see http://cshperspectives.cshlp.org/cgi/collection/

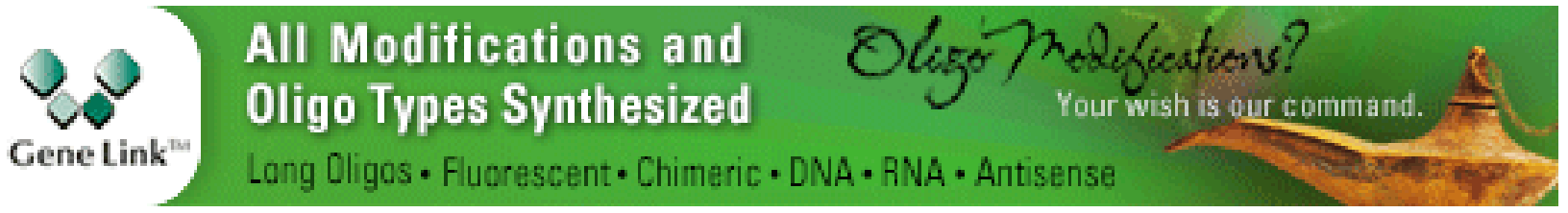

Copyright @ 2018 Cold Spring Harbor Laboratory Press; all rights reserved 
Role of the $\beta$ Common $(\beta \mathrm{c})$ Family of Cytokines in Health and Disease

Timothy R. Hercus, Winnie L. T. Kan, Sophie E. Broughton, et al.

Interleukin (IL)-12 and IL-23 and Their Conflicting Roles in Cancer Juming Yan, Mark J. Smyth and Michele W.L. Teng
Negative Regulation of Cytokine Signaling in Immunity

Akihiko Yoshimura, Minako Ito, Shunsuke Chikuma, et al.

Cancer Inflammation and Cytokines

Maria Rosaria Galdiero, Gianni Marone and Alberto Mantovani

For additional articles in this collection, see http://cshperspectives.cshlp.org/cgi/collection/

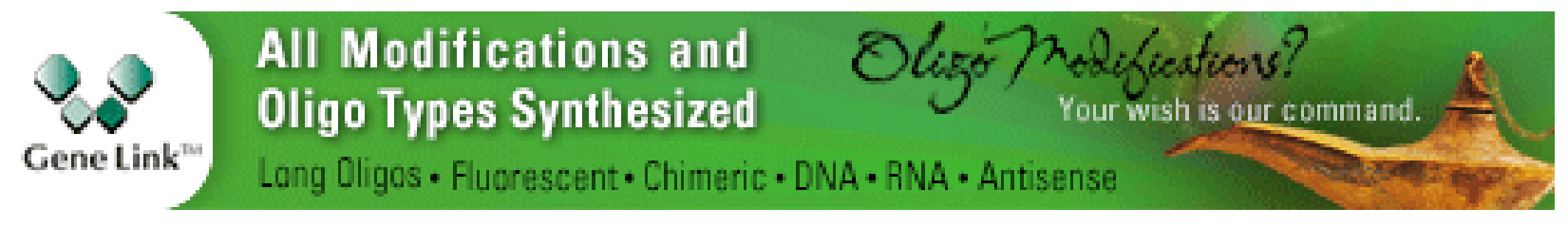

Copyright @ 2018 Cold Spring Harbor Laboratory Press; all rights reserved 